\title{
Novel 1,3-diethyl-2-thiobarbiturates of 2,2'-bipyridine and 1,10-phenanthroline: synthesis, crystal structure and thermal stability
}

Nicolay N. Golovnev ${ }^{a}$, Maxim S. Molokeev ${ }^{b, a, c^{*}}$, Irina V. Sterkhova ${ }^{d}$ Maxim K. Lesnikov $^{a}$,

${ }^{a}$ Siberian Federal University, 79 Svobodny Ave., Krasnoyarsk 660041, Russia

${ }^{b}$ Laboratory of Crystal Physics, Kirensky Institute of Physics, Federal Research Center KSC SB RAS, bld. 38 Akademgorodok 50, Krasnoyarsk 660036, Russia

${ }^{c}$ Department of Physics, Far Eastern State Transport University, 47 Seryshev Str., Khabarovsk 680021, Russia

${ }^{d}$ Favorsky Institute of Chemistry, Siberian Branch, Russian Academy of Sciences, 1 Favorsky, Irkutsk 664033, Russia

* Corresponding author:

Maxim Molokeev

E-mail: msmolokeev@gmail.com

Laboratory of Crystal Physics, Kirensky Institute of Physics, Federal Research Center KSC SB RAS, bld. 38 Akademgorodok 50, Krasnoyarsk 660036, Russia

Tel.: +7-391-249-45-07

$\dagger$ Electronic supplementary information (ESI) available. See DOI:xxx

\begin{abstract}
The co-crystallization of 1,3-diethyl-2-thiobarbituric acid (HDetba) with 2,2'-bipyridine (Bipy) and 1,10-phenanthroline (Phen) in aqueous medium are prepared a salt co-crystal, BipyH(Detba)(HDetba) (1), and the salt, PhenH(Detba) $\mathrm{H}_{2} \mathrm{O}$ (2). The compounds have been characterized by single-crystal and powder X-ray diffraction, and TG-DSC. The nitrogen atoms of $\mathrm{BipyH}^{+}$adopt an cis conformation with the $\mathrm{N}-\mathrm{C}-\mathrm{C}-\mathrm{N}$ torsion angle is $-17.3(1)^{\mathrm{o}}$. There are six intermolecular hydrogen bonds $\mathrm{O}-\mathrm{H} \cdots \mathrm{O}, \mathrm{N}-\mathrm{H} \cdots \mathrm{O}, \mathrm{C}-\mathrm{H} \cdots \mathrm{O}$ and $\mathrm{C}-\mathrm{H} \cdots \mathrm{S}$ in (1) which form 2D plane network. The Detba ${ }^{-}$ion and HDetba molecule form pair by means of hydrogen bonds. The Detba ${ }^{-}$anions in (2) do not form dimers, they are connected by $\mathrm{N}-\mathrm{H} \cdots \mathrm{O}$, $\mathrm{C}-\mathrm{H} \cdots \mathrm{S}$ and $\mathrm{C}-\mathrm{H} \cdots \mathrm{O}$ hydrogen bonds only with $\mathrm{PhenH}^{+}$cations and water molecules which form 3D net. The different $\pi-\pi$ interactions between the rings are found in the (1)-(2). The compounds are characterized by powder XRD, TG-DSC.
\end{abstract}

Keywords: 1,3-diethyl-2-thiobarbituric acid; 1,10-phenanthroline; 2,2'-bipyride; ; salt; salt cocrystal; X-ray diffraction; infrared spectroscopy; thermal stability

\section{Introduction}

Derivatives of barbituric acid have anesthetic, sedative, anticonvulsive, antimicrobial, antifungal, antiviral and anti-cancer properties $[1,2]$. Moreover, the organic salts of barbituric 
acids and their metal complexes possess potentially useful properties, for instance, biological activities [3, 4], solvatochromism, molecular recognition, photoluminescence, catalytic activity etc. [2]. They are promising materials of nonlinear optics (NLO) [5, 6] and organic solar cells [7]. The structures of metal complexes with barbituric $\left(\mathrm{H}_{2} \mathrm{ba}\right)$ and 2-thiobarbituric acids $\left(\mathrm{H}_{2} \mathrm{tba}\right)$ and some of their derivatives have been mainly studied $[8,9]$. Organic salts and co-crystalls of barbituric acids are less studied, for example, there are no structural data on the compounds of 1,3-diethyl-2-thiobarbituric acid $\left(\mathrm{C}_{8} \mathrm{H}_{12} \mathrm{~N}_{2} \mathrm{O}_{2} \mathrm{~S}\right.$, HDetba) (Fig. 1), although it and its compounds can find practical application. For example, HDetba is proposed as an alternative to acidic photopolymerizable dental materials [10] and for determining nicotine and twelve metabolites in human urine and animals using high-performance liquid chromatography [11]. Its compounds can be used as NLO materials [12] and for the manufacture of field-effect transistors [13]. Like the $\mathrm{H}_{2}$ tba, HDetba has five potential hydrogen bonding acceptors: (i) two carbonyl $\mathrm{O}$ atoms, (ii) one $\mathrm{S}$ atom and (iii) two $\mathrm{N}$ atoms. Each of the two $\mathrm{N}$ atoms is linked to one -C2H5 group and therefore can only act as a weak hydrogen bonding acceptor. In the absence of the strong hydrogen bonding donors in HDetba, they can be replaced by $\mathrm{C}$ atoms, forming the weak $\mathrm{C}$ $\mathrm{H}^{\cdots} \mathrm{Y}$ hydrogen bonds ( $\left.\mathrm{Y}=\mathrm{F}, \mathrm{O}, \mathrm{N}\right)$ [14]. Therefore, further exploration of organic systems of 1,3-diethyl-2-thiobarbituric acid can provide abundant supramolecular architectures.

The free bases of 2,2'-bipyridine (Bipy) and 1,10-phenanthroline (Phen) are used as the complexing agents for iron and other metal ions in chemical and biological systems. A classical use of Phen is that of the Fe(II)-complex (ferroin) as an indicator in redox titrations [15]. Bipy is a very interesting ligand because of its potential application in the preparation of nonlinear optical materials (NLO), sensor objects, coatings and catalysis [16], single-molecule magnets [17]. As a part of our continuing investigations on structures and properties of 1,3-diethyl-2thiobarbiturate compounds [18-26], in the present report a salt co-crystal 2,2'-bipyridin-1-ium 1,3-diethyl-2-thiobarbiturate1,3-diethyl-2-thiobarbituric acid, BipyH(Detba)(HDetba) (1), and a salt phenanthrolin-1-ium 1,3-diethyl-2-thiobarbiturate monohydrate, $\mathrm{PhenH}(\mathrm{Detba}) \cdot \mathrm{H}_{2} \mathrm{O}(2)$, were synthesized and characterized by single-crystal and powder X-ray diffraction methods. Also thermal decomposition of compounds was studied. Thermal decomposition of compounds was also studied. Any information on the structure of the solid and the properties of Bipy or Phen compounds with HDetba is not found in the scientific literature [9].

\section{Experimental section}

\subsection{Reagents and synthesis}

1,3-diethyl-2-thiobarbituric acid, 1,10-phenanthrolinium chloride monohydrate and 2,2'bipyridine were purchased from Sigma-Aldrich and used without further purification. Sodium 
hydroxide and ethanol (95\%, CAS 64-17-5) as a reagents analytical grade (Acros) were used without additional purification.

Compound BipyH(Detba)(HDetba) (1) was prepared by the crystallization from the ethanol. 2,2'-bipyridine (0.039 g, $2.5 \mathrm{mmol})$ and 1,3-diethyl-2-thiobarbituric acid (0.1 g, $5.0 \mathrm{mmol})$ were dissolved in ethanol $\left(1.5 \mathrm{~cm}^{3}\right)$ at room temperature. A light yellow transparent solution was left at a temperature of $3{ }^{\circ} \mathrm{C}$. After 2 days, the formation of yellow rhombic single crystals was observed. The crystalline product was filtered off and dried between sheets of filter paper in air at room temperature (yield 67\%). The single crystals suitable for structural analysis were selected directly from the total mass of precipitate (1). The elemental analysis for $\mathrm{C}_{26} \mathrm{H}_{32} \mathrm{~N}_{6} \mathrm{O}_{4} \mathrm{~S}_{2}$ (1): Calc.: C, 56.1\%; H, 5.79\%; N, 15.1\%; S, 11.5\%. Found: C, 56.7\%; H, 5.58\%; N, 14.9\%; S, 11.2\%. Also compound (1) was crystallizes from the aqueous solution at $\mathrm{pH}=3.1$ (a multitest IPL-103 pH meter, Semico, Russia) with yield 40-60\%. The repeated experiments showed poor reproducibility of this method.

The salt, PhenH(Detba) $\mathrm{H}_{2} \mathrm{O}$ (2), was crystallized from the water. 1,10-phenanthroline hydrochloride monohydrate $(0.117 \mathrm{~g}, 5.0 \mathrm{mmol}))$ was dissolved in $5 \mathrm{ml}$ of water and then an equimolar amount of solid $\mathrm{NaOH}$ was added. A white precipitate of Phen was formed. Then to this mixture the 1,3-diethyl-2-thiobarbituric acid $(0.1 \mathrm{~g}, 5.0 \mathrm{mmol})$ was added. The sediment partially dissolved, changing color from white to yellow. The mixture was heated to $80{ }^{\circ} \mathrm{C}$ and kept at this temperature for one hour until the yellow precipitate dissolves completely. The light yellow solution was slowly cooled and allowed to evaporate at room temperature $(\mathrm{pH}=3.9)$. A week later, a little amount of orange oil was formed in the solution, the amount of which was increased as the water evaporated. The solid residue after complete removal of water was a mixture of orange crystals and a glassy substance. The orange single crystals of (2) were taken directly from the resulting mixture. Several these single crystals are used for the structural analysis and thermal measurements. However, we could not get compound (2) at a volume sufficient for powder XRD measurements. The attempts to obtain other compounds of HDetba with Bipy and Phen by the crystallization from an aqueous solution were unsuccessful.

\subsection{X-ray diffraction analysis}

The intensity patterns were collected from single crystals (1) and (2) at $100 \mathrm{~K}$ using the D8 Venture X-ray single crystal diffractometer (Bruker AXS) equipped with a CCD-detector, graphite monochromator and a Mo K $\alpha$ radiation source. The absorption corrections were applied using the SADABS program. The structures were solved by the direct methods using package SHELXS and refined in the anisotropic approach for non-hydrogen atoms using the SHELXL program [27]. All hydrogen atoms were found via Fourier difference maps. Further, the 
hydrogen atoms, which are linked with $\mathrm{C}, \mathrm{N}$ atoms in the HDetba molecule, Detba ${ }^{-}, \mathrm{BipyH}^{+}$, $\mathrm{PhenH}^{+}$ions in 1, 2 were positioned geometrically as riding on their parent atoms with $\mathrm{d}(\mathrm{C}-\mathrm{H})$ $=0.93-0.98 \AA, \mathrm{d}(\mathrm{N}-\mathrm{H})=0.86-0.89 \AA$ depending on geometry and $\mathrm{U}_{\mathrm{iso}}(\mathrm{H})=1.2 \mathrm{U}_{\text {eq }}(\mathrm{C}, \mathrm{N})$. All hydrogen atoms of the $\mathrm{H}_{2} \mathrm{O}$ molecules were refined with bond length restraint $\mathrm{d}(\mathrm{O}-\mathrm{H})=0.9 \AA$ and $\mathrm{U}_{\mathrm{iso}}(\mathrm{H})=1.2 \mathrm{U}_{\mathrm{eq}}(\mathrm{O})$. The structure test for the presence of missing symmetry elements and possible voids was produced using the PLATON program [28]. The DIAMOND program is used for the crystal structure plotting [29].

Powder X-ray diffraction data of (1) was obtained using diffractometer D8 ADVANCE (Bruker) equipped by a VANTEC detector with a Ni filter. The measurements were made using $\mathrm{Cu} \mathrm{K \alpha}$ radiation. The structural parameters defined by a single crystal analysis were used as a base in the powder pattern Rietveld refinement. The refinement was produced using program TOPAS 4.2 [30]. The low $R$-factor and the good refinement results (Table 1S, Fig. 1S) indicate the phase purity of the powder sample (1).

\subsection{Physical measurements}

TGA was carried out on the simultaneous SDT-Q600 thermal analyzer (TA Instruments, USA) under the dynamic air atmosphere $\left(50 \mathrm{ml} / \mathrm{min}\right.$ flow rate) within $25-350{ }^{\circ} \mathrm{C}$ at the scan rate of $10{ }^{\circ} \mathrm{C} / \mathrm{min}$. The compound weight was $4.516 \mathrm{mg}$ for (1) and $4.590 \mathrm{mg}$ for (2). Platinum crucibles with perforated lids were used as the containers. The IR absorption spectra of the compounds inserted into the $\mathrm{KBr}$ tablets were recorded over the range of $400-4000 \mathrm{~cm}^{-1}$ at room temperature on an FT-IR spectrometer Nicolet 6700 (Thermo Scientific, USA, SFU CEJU).

\section{Results and discussion}

\subsection{Theoretical consideration}

2,2'-bipyridine and 1,10-phenanthroline behave as weak bases, often forming monoprotonated species of $\mathrm{BipyH}^{+}$and $\mathrm{PhenH}^{+}$, respectively, as a result of protonation of one $\mathrm{N}$ atom. In aqueous solution the stepwise acidity constants are $\mathrm{pK}_{\mathrm{a} 1}=1.51, \mathrm{pK}_{\mathrm{a} 2}=4.48$ for the $\mathrm{BipyH}_{2}{ }^{2+}$, and $\mathrm{pK}_{\mathrm{a} 1}=1.92, \mathrm{pK}_{\mathrm{a} 2}=5.01$ for the $\mathrm{PhenH}_{2}{ }^{2+}\left(30{ }^{\circ} \mathrm{C}, 0.1 \mathrm{M} \mathrm{KNO}_{3}\right)$ [31]. The acidity constant is $\mathrm{pK}_{\mathrm{a} 1}=2.78$ for $\mathrm{HDetba}\left(25^{\circ} \mathrm{C}, 0.25 \mathrm{M} \mathrm{KCl}\right)$ [32]. The HDetba speciation (Fig. 2) shows the predominance of an anionic species at $\mathrm{pH}>4\left(\alpha_{1} \approx 1\right)$, and a neutral species at $\mathrm{pH}<$ $1.5\left(\alpha_{2} \approx 1\right)$ in aqueous solution. The neutral molecule Bipy species (Fig. 2$)$ is dominated at $\mathrm{pH}$ $>6\left(\alpha_{0} \approx 1\right)$, a cationic species BipyH $^{+}$between $\mathrm{pH} 2$ and $\mathrm{pH} 4\left(\alpha_{1} \approx 0.7-0.8\right)$. A diprotonated cationic species $\mathrm{BipyH}_{2}{ }^{2+}\left(\alpha_{2}\right)$ forms already at $\mathrm{pH}<3$, and it is dominated at $\mathrm{pH}<1$. The speciation of Phen - HDetba system (Fig. 2S) shows the predominance of a neutral Phen species 
at $\mathrm{pH}>6.5$, a cationic species $\mathrm{PhenH}^{+}$between $\mathrm{pH} 2.5$ and $\mathrm{pH} 4.5$, and a cationic species $\mathrm{PhenH}_{2}{ }^{2+}$ at $\mathrm{pH}<1$. According to the species distribution diagrams, $\mathrm{pH}$ values of aqueous solution were chosen for synthesis $(\mathbf{1})[\mathrm{pH} \approx 3]$ and $(\mathbf{2})[\mathrm{pH} \approx 4]$.

It is generally accepted that the reaction of an acid with the base is expected to form a salt if $\Delta \mathrm{pK}_{\mathrm{a}}=\mathrm{pK}_{\mathrm{a}}$ (base) $-\mathrm{pK}_{\mathrm{a}}$ (acid) $>2$ or 3 [33]. Indeed, when the equimolar amounts of HDetba interact with Phen $(\Delta \mathrm{pK}$ BipyH $^{+}$и HDetba is less $\left(\Delta \mathrm{pK}_{\mathrm{a}}=1.70\right)$, which promoted the formation of $(\mathbf{1})$ salt co-crystals at pH 3.

\subsection{Crystal structures of (1)}

The unit cells of (1) correspond to the triclinic symmetry. Space group $P-1$ was determined from the statistical analysis of the reflection intensities. The main crystal data are enumerated in Table 1. The compound (1) is a salt co-crystal [34]. The independent part of the unit cell contains one $\mathrm{BipyH}^{+}$ion, one Detba ${ }^{-}$ion and one HDetba molecule (Fig. 3a). The main bond lengths $\mathrm{C}-$ $\mathrm{N}, \mathrm{C}-\mathrm{C}$ and valence angles (Table $2 \mathrm{~S}$ ) practically coincide with those found earlier in other related compounds of HDetba [18-26], but $\mathrm{C}-\mathrm{S}$ and $\mathrm{O} 1-\mathrm{C} 4$ bonds are slightly (0.01-0.02 $⿱$ A) shorter. However, the $\mathrm{O} 2 \mathrm{~A}-\mathrm{C} 6 \mathrm{~A}$ bond is noticeably $(0.03-0.04 \AA)$ longer than the others (Table $2 \mathrm{~S}$ ), since the $\mathrm{O} 2 \mathrm{~A}$ atom in the HDetba molecule is bonded to the hydrogen atom, that is, the HDetba acid is in the enol form. The conformations of Bipy and its protonated species constitute an important aspect in the understanding of the properties of this popular ligand in coordination chemistry. Bipy exists in a trans conformation in the solid state [35]. The cis conformer of the cation is by far the most stable than trans, according to ab initio self consistentfield (SCF) calculation [36]. As expected, 2,2'-bipyridine offers interesting motifs by virtue of the predominantly cis dispositions of the pairs of nitrogen atoms in its monoprotonated salts [8]. The monoprotonated cis species of $\mathrm{BipyH}^{+}$could be stabilized by a cationic hydrogen bond $\mathrm{N}-$ $\mathrm{H}^{\cdots} \mathrm{N}$, as in numerous proton sponges [14]. However, there are also compounds in which $\mathrm{BipyH}^{+}$is in the form of a trans conformer $[8,37]$. In (1), the bipyridinium cation has a cis conformation and the $\mathrm{N}-\mathrm{C}-\mathrm{C}-\mathrm{N}$ torsion angle is $-17.3(1)^{\circ}$. It clearly indicates that $\mathrm{BipyH}^{+}$ does not behave as a proton sponge. As expected [38], an weak intramolecular hydrogen bond is found in the $\mathrm{BipyH}^{+}$cation with an $\mathrm{N} 2 \cdots \mathrm{N} 1$ distance of 2.654(1) $\AA$ and $\mathrm{N} 2-\mathrm{H}^{\cdots} \mathrm{N} 1$ angle of 106.52(7) $)^{\mathrm{o}}$. The main bond lengths $\mathrm{C}-\mathrm{N}, \mathrm{C}-\mathrm{C}$ and the angles in the $\mathrm{BipyH}^{+}$practically coincide with those found earlier in other related compounds [8]. For instance, the bond lengths

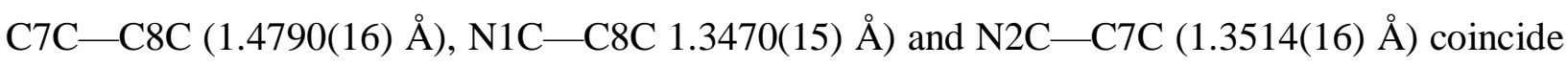
with those found in $[\mathrm{BipyH}] \mathrm{ClO}_{4}[\mathrm{C} 7 \mathrm{C}-\mathrm{C} 8 \mathrm{C}(1.481 \AA), \mathrm{N} 1 \mathrm{C}-\mathrm{C} 8 \mathrm{C} 1.347 \AA)$ and $\mathrm{N} 2 \mathrm{C}-\mathrm{C} 7 \mathrm{C}$ $(1.352 \AA)$ ] (CSD refcode PYPYPC02) [39]. In (1), the $\mathrm{BipyH}^{+}$ion is a planar, the standard 
deviation of atoms from this plane is $0.183 \AA$. As expected [40], the effect of protonation at the $\mathrm{N} 2$ site in $\mathrm{BipyH}^{+}$, is manifested in the $\mathrm{C}-\mathrm{N}-\mathrm{C}$ angles being much wider than those at the unprotonated $\mathrm{N} 1$ atom $\left[123.4(1)^{\circ}\right.$ versus $\left.117.2(1)^{\circ}\right]$. There are six intermolecular hydrogen bonds $\mathrm{O}-\mathrm{H} \cdots \mathrm{O}, \mathrm{N}-\mathrm{H} \cdots \mathrm{O}, \mathrm{C}-\mathrm{H} \cdots \mathrm{O}$ and $\mathrm{C}-\mathrm{H} \cdots \mathrm{S}$ in the structure (Table 2) which form 2D plane network with the supramolecular motifs $R_{2}{ }^{1}(6), R_{2}{ }^{1}(7)$ and $R_{8}{ }^{8}(39)$ (Figure 4a). The one Detba $^{-}$ion and one HDetba molecule join to form pairs by means of $\mathrm{O} 2 \mathrm{~A}-\mathrm{H} 1 \mathrm{~A} \cdots \mathrm{O} 2 \mathrm{~B}$ and $\mathrm{C} 5 \mathrm{~A}-\mathrm{H} 5 \mathrm{~A} \cdots \mathrm{O} 2 \mathrm{~B}$ hydrogen bonds. In the salt co-crystal (1), a strong hydrogen bond $\mathrm{O} 2 \mathrm{~A}-$ $\mathrm{H} 1 \mathrm{~A} \cdots \mathrm{O} 2 \mathrm{~B}$ is characterized by a small distance $\mathrm{d}(\mathrm{O} \cdots \mathrm{O})=2.440$ (1) $\AA$, a large value of the angle $\mathrm{O} 2 \mathrm{~A}-\mathrm{H} 1 \mathrm{~A} \cdots \mathrm{O} 2 \mathrm{~B}\left(178(2)^{\circ}\right)$ and a long bond $\mathrm{O} 2 \mathrm{~A}-\mathrm{H} 1 \mathrm{~A}(\mathrm{~d}(\mathrm{O} 2 \mathrm{~A}-\mathrm{H} 1 \mathrm{~A})=1.32(2) \AA)$. The close geometric parameters of the hydrogen bond $\mathrm{O}-\mathrm{H} \cdots \mathrm{O}$ were previously established in the salt co-crystal of the piperidine (Pipe) with 2-thiobarbituric acid, $\mathrm{PipeH}(\mathrm{Htba})\left(\mathrm{H}_{2} \mathrm{tba}\right)(3)$ [41]. In the formation of strong hydrogen bonds, the increase in the distance $d(\mathrm{O}-\mathrm{H})$ reaches $0.2 \AA$ [42] as in compound (1). In (3), the $\mathrm{Htba}^{-}$ion and the $\mathrm{H}_{2}$ tba molecule also form a pair, but due to two hydrogen bonds $\mathrm{N}-\mathrm{H} \cdots \mathrm{O}$. These pairs are combined by the intermolecular hydrogen bonds $\mathrm{O}-\mathrm{H} \cdots \mathrm{O}$ and $\mathrm{N}-\mathrm{H} \cdots \mathrm{O}$ into infinite chains. Replacing the hydrogen atoms of the $\mathrm{NH}$ groups in $\mathrm{H}_{2}$ tba by the $\mathrm{C}_{2} \mathrm{H}_{5}$ groups leads to a weakening of the $\mathrm{N}$ atoms donor capacity. In this case, weak $\mathrm{C}-\mathrm{H} \cdots \mathrm{O}$ hydrogen-bonds in (1) play an important role in the formation of the supramolecular structure. The $\mathrm{C}-\mathrm{H} \cdots \mathrm{O}$ hydrogen-bond distances in (1) are of the same order of magnitude as those reported previously [37].

Topological analysis of the net, using simplification and excluding all 0-, 1- and 2coordinated nodes revealed that this is uninodal 4-c net with point symbol $\left(4^{3} .6^{3}\right)$ which is known as SP (6,3)Ia [30]. It should be noted that $\mathrm{H}$-bond net of $\mathrm{NH}_{4}$ Detba [18] form relative 2D net with point symbol $\left(4^{4} \cdot 6^{2}\right)$ named sql. The compounds LiDetba and NaDetba [19] have relative $2 \mathrm{D}$ nets $\left(4^{2} .6^{4}\right)$ named $\mathbf{S P}(\mathbf{6 , 3}) \mathbf{I d}$. The compounds $\mathrm{M}(\mathrm{Detba})_{2}\left(\mathrm{H}_{2} \mathrm{O}\right)_{2}(\mathrm{M}=\mathrm{Ca}, \mathrm{Sr}, \mathrm{Mn})$ $[23,26]$ also have $2 \mathrm{D}$ nets $\left(4^{4} .6^{2}\right) \mathbf{s q l}$, the compound $E u(\text { Detba })_{3}[24]$ has $2 \mathrm{D}$ net $\left(6^{3}\right) \mathbf{h c b}$, and $\mathrm{Pb}$ (Detba) 2 [21] has 2D net $\left(4^{3}\right)_{2}\left(4^{4} \cdot 6^{6} .8^{3}\right) \mathrm{kgd}$. The common of all these nets is that they form only $2 \mathrm{D}$ nets and this can be associated with small amount hydrogen bond donors in HDetba ligands. Further analysis of interactions in (1) revealed $\pi-\pi$ interactions between HDetba, Detba and $\mathrm{BipyH}^{+}$rings (Table 3S, Fig. 3Sa).

\subsection{Crystal structures of (2)}

The unit cell of (2) also corresponds to triclinic symmetry. The main crystal data are shown in Table 1. The independent part of the unit cell contains two Detba ${ }^{-}$ions, two $\mathrm{PhenH}^{+}$ions and two water molecules. (Fig. 3b). The structure test for the presence of missing symmetry elements revealed nonspacegroup translation $\mathrm{A}(0,1 / 2,1 / 2)$. As far as groups of atoms $(\mathrm{O} 1 \mathrm{C}, \mathrm{O} 1 \mathrm{D})$; 
(C9C, C9D); (O1W, O2W) violated this translation so the crystal has pseudosymmetry and no obvious spacegroup change needed. The main bond lengths $\mathrm{C}-\mathrm{N}, \mathrm{C}-\mathrm{C}$ (Table $2 \mathrm{~S}$ ) and the valence angles in $\mathrm{HDetba}^{-}$ion coincide with those found earlier in other related compounds [18-26] and like in (1) $\mathrm{C}-\mathrm{S}$ and $\mathrm{O} 1-\mathrm{C} 4$ bonds are slightly (0.01-0.02 $\AA$ ) shorter. Also in $\mathrm{PhenH}^{+}$, the $\left.\mathrm{C} 1 \mathrm{~A}-\mathrm{C} 2 \mathrm{~A}(1.434(2) \AA), \mathrm{C} 1 \mathrm{~B}-\mathrm{C} 2 \mathrm{~B} 1.436(2) \AA\right), \mathrm{N} 1 \mathrm{~A}-\mathrm{C} 2 \mathrm{~A}$ (1.363(2) $\AA$ ), $\mathrm{N} 1 \mathrm{~B}-\mathrm{C} 2 \mathrm{~B}(1.363(2) \AA), \quad \mathrm{N} 2 \mathrm{~A}-\mathrm{C} 1 \mathrm{~A}(1.357(2) \AA)$, and N2B-C1B (1.359(2) $\mathrm{A})$ distances are coincided with those found earlier (CSD refcode CUZDIK) [43]. $\mathrm{PhenH}^{+}$ions are practically flat, so the standard deviation of atoms from planes for ions A and B is only 0.048 and $0.052 \AA$, respectively. As in compound (1), the effect of protonation at the $\mathrm{N} 2 \mathrm{~A}$ and $\mathrm{N} 2 \mathrm{~B}$ sites in $\mathrm{A}$ and $\mathrm{B}$ respectively, is manifested in the $\mathrm{C}-\mathrm{N}-\mathrm{C}$ angles being much wider than those at the unprotonated nitrogen atoms $\left[123.1(1), 123.0(1)^{\circ}\right.$ versus $\left.116.5(1), 116.4(1)^{\circ}\right]$. Just like in (1), a weak intramolecular hydrogen bond is found in $\mathrm{A}$ and $\mathrm{B}$ of $\mathrm{PhenH}^{+}$cation with an $\mathrm{N} 2 \cdots \mathrm{N} 1$ distance of $2.7476(2) \AA$ and $2.7517(2) \AA$, and $\mathrm{N}-\mathrm{H} \cdots \mathrm{N}$ angle of $104.121(9)^{\mathrm{o}}, 104.31(1)^{\mathrm{o}}$, respectively. The torsion angle $\mathrm{C} 8-\mathrm{C} 7-\mathrm{C} 9-\mathrm{C} 10$ of Detba ${ }^{-}$ions in (1) $-(\mathbf{2})$ are small ( $\left.<4 \mathrm{deg}\right)$ therefore the Detba- ions present in conformational state (A). The torsion angle C8-C7-C9-C10 for Detba ${ }^{-}$ions in (1)-(2) is small $(<4 \mathrm{deg})$ therefore Detba ions are represented only a conformer (A) [18].

There are nine intermolecular hydrogen bonds $\mathrm{N}-\mathrm{H} \cdots \mathrm{O}, \mathrm{O}-\mathrm{H} \cdots \mathrm{O}, \mathrm{C}-\mathrm{H} \cdots \mathrm{O}$ and $\mathrm{C}-$ $\mathrm{H} \cdots \mathrm{S}$, in the structure (Table 2) which form 3D net. Some 2D nets can be marked (Fig. 4b) and the shortest ring motifs in them are $\mathrm{R}_{4}{ }^{4}(18), \mathrm{R}_{4}{ }^{4}(20), \mathrm{R}_{6}{ }^{6}(20)$. The water molecules participate in moderately strong $\mathrm{O}-\mathrm{H} \cdots \mathrm{O}$ interaction with anions $(\mathrm{d}(\mathrm{O} \cdots \mathrm{O})=2.809$ and $2.876 \AA$ $)$. Also, there are $\pi-\pi$ interactions between Detba $^{-}$and $\mathrm{PhenH}^{+}$rings (Table $3 \mathrm{~S}$, Fig. 3Sb). The self-assembly, and crystal structure for 1,10-phenanthrolinium barbiturate monohydrate, $\mathrm{PhenH}(\mathrm{Hba}) \cdot \mathrm{H}_{2} \mathrm{O}$ (CSD refcode MUYVET), and 1,10-phenanthrolinium 2-thiobarbiturate, PhenH(Htba) (CSD refcode MUYVET), are reported earlier [5]. In them two barbiturate or thiobarbiturate moieties join to form dimers by means of $\mathrm{N}-\mathrm{H} \cdots \mathrm{O}$ hydrogen bonds (2.805 and $2.823 \AA$ ). These dimers are stabilized by the cation-anion interactions of $\mathrm{N}-\mathrm{H} \cdots \mathrm{O}$ and $\mathrm{N}-\mathrm{H} \cdots \mathrm{N}$ types. As in (2), the water molecules in $\mathrm{PhenH}(\mathrm{Hba}) \cdot \mathrm{H}_{2} \mathrm{O}$ participate in the formation of moderately strong hydrogen bonds with $\mathrm{Hba}^{-}$anions. Just like in (1)-(2), in $\mathrm{PhenH}(\mathrm{Hba}) \cdot \mathrm{H}_{2} \mathrm{O}$ and $\mathrm{PhenH}(\mathrm{Htba})$ the $\mathrm{C}-\mathrm{N}-$ $\mathrm{C}$ angles for protonated $\mathrm{N}$ atoms больше чем at the unprotonated $\mathrm{N}$ atoms, and the charge in $\mathrm{O} 1=\mathrm{C} 4-\mathrm{C} 5-\mathrm{C} 6=\mathrm{O} 2$ group of $\mathrm{Hba}^{-}$and $\mathrm{Htba}^{-}$is delocalized.

Topological analysis of (2) using ToposPro program [30] showed that this 3D net is 6nodal (3-c)(4-c)(4-c)(5-c)(5-c)(5-c) net with point symbol $\left(3.4 .5 .6^{3}\right)\left(3.4 .6^{5} .7^{2} .8\right)\left(3.4^{2} .5 .6^{2}\right)(4.6 .8)\left(4^{2} .6^{5} .7^{2} .8\right)\left(4^{3} .6^{6} .7\right)$ which is new. 


\subsection{Thermal decomposition}

The TG-DSC curves of BipyH(Detba) (1) and(PhenH(Detba) $\mathrm{H}_{2} \mathrm{O}$ (2) at $25-300{ }^{\circ} \mathrm{C}$ are shown in Fig. 4S and Fig. 5S, respectively. The TG curve clearly indicated that thermal decomposition/oxidation of (1) occurs in one step (Fig. 4S). An endothermic effect for (1) at $110.3{ }^{\circ} \mathrm{C}$ corresponds to the compound melting. This value of melting point is higher than for Bipy $\left(70.5^{\circ} \mathrm{C}\right)$ and less than for HDetba $\left(112^{\circ} \mathrm{C}\right.$, [19]), that confirms the individuality of the compound (1). The decrease in the mass of the substance at $\mathrm{T}>112{ }^{\circ} \mathrm{C}$ corresponds to the oxidation of compound and evaporation of HDetba and Bipy. In the range of $150-230{ }^{\circ} \mathrm{C}$, the mass of the sample decreased rapidly in accordance to the mean TG curve (Fig. 4S). The transformations at $150-230{ }^{\circ} \mathrm{C}$ are accompanied by the exo effect at $\sim 160{ }^{\circ} \mathrm{C}$ and endo effect at $216{ }^{\circ} \mathrm{C}$. The appearance of a weak endothermic peak at $216{ }^{\circ} \mathrm{C}$ can be explained by the thermal effects superposition of oxidative decomposition and evaporation of thermolysis products. In the temperature range of $150-230^{\circ} \mathrm{C}$, almost all the bipyridine is removed, which is confirmed by the absence of an endothermic effect at the boiling point of Bipy $\left(273{ }^{\circ} \mathrm{C}\right)$. At $250{ }^{\circ} \mathrm{C}$, the total mass loss reaches $\sim 95 \%$, and then the mass decreases only by $\sim 1 \%$ when heated to $300{ }^{\circ} \mathrm{C}$. The carbonaceous residue $(\sim 5 \%)$ is probably formed as a result of incomplete oxidation of the HDetba molecules and Detba ${ }^{-}$ions with the release of $\mathrm{CO}_{2}$. As seen from the TG curve (Fig. 5S), the thermal decomposition process for the (2) can be divided into three stages. The first stage starts in the range of $70-135^{\circ} \mathrm{C}$ with mass loss of $4.60 \%$, which corresponds to the loss of $\mathrm{H}_{2} \mathrm{O}$ molecule with the theoretical mass loss of $4.52 \%$. The Phen and HDetba have melting point of $117^{\circ} \mathrm{C}$ and $112{ }^{\circ} \mathrm{C}$ [19], respectively, these data confirm the individuality of the compound (2). The dehydration of (2) is accompanied by endo effect at $93.6{ }^{\circ} \mathrm{C}$. In the second stage of transformation at $140-250{ }^{\circ} \mathrm{C}$, evaporation and oxidation of 1,3-diethyl-2-thiobarbituric acid and phenanthroline occur simultaneously. In the third stage, above $250{ }^{\circ} \mathrm{C}$, the endothermic evaporation processes of HDetba and Phen are likely to become increasingly important, as evidenced by the endothermic peak at $275{ }^{\circ} \mathrm{C}$ on the DSC curve. The thermolysis final product of (2) at $310{ }^{\circ} \mathrm{C}$ consists predominantly of liquid Phen, that agrees with its boiling point (300 $\left.{ }^{\circ} \mathrm{C}\right)$. 


\section{Conclusions}

For the first time, the organic salt co-crystal (1) and salt (2) of 1,3-dialkyl-2-thiobarbituric acid are prepared and structurally characterized. The compounds were obtained by reaction in an aqueous medium of an acid with the Bipy and Phen. At a Bipy : HDetba =1: 2 molar ratio, an anhydrous salt co-crystal (1) forms containing in the formula unit one monoprotonated 2,2bipyridine, one deprotonated acid anion, Detba ${ }^{-}$, and neutral acid, HDetba. The salt (2) was obtained by reaction of an acid with the 1,10-phenanthroline at a Phen : HDetba $=1: 1$ molar ratio. It contains one $\mathrm{PhenH}^{+}$cation, one $\mathrm{Detba}^{-}$anion and one water molecule. Образование солевого со-кристалла (1) и соли (2) согласуется с “ $\Delta \mathrm{pK}_{\mathrm{a}}$ rule” предложенным ранее для двухкомпонентных органических кристаллов[33].

The protonation of the $\mathrm{N}$ atom in (1) and (2) results in a slight deformation of the ring and consequently a slightly larger $\mathrm{C}-\mathrm{N}-\mathrm{C}$ bond angle $\left(>120^{\circ}\right)$. In $(\mathbf{1})$, the $\mathrm{O}-\mathrm{H} \cdots \mathrm{O}$ and $\mathrm{C}-\mathrm{H} \cdots \mathrm{O}$ intermolecular hydrogen bonds connect the anion and neutral acid in pair. The $\mathrm{O}-\mathrm{H} \cdots \mathrm{O}$ hydrogen bond between an acid (HDetba) and its conjugate base (Detba ${ }^{-}$) is very strong with $\mathrm{d}(\mathrm{O} \cdots \mathrm{O})=2.440(1) \AA$. The Detba ${ }^{-}$anion is bound to one $\mathrm{BipyH}^{+}$ion by two $\mathrm{N}-\mathrm{H} \cdots \mathrm{O}$ and $\mathrm{C}-$ $\mathrm{H} \cdots \mathrm{O}$ intermolecular hydrogen bonds (Fig. 4a). HDetba is bound by two $\mathrm{C}-\mathrm{H} \cdots \mathrm{O}$ intermolecular hydrogen bonds with one $\mathrm{BipyH}^{+}$cation and $\mathrm{C}-\mathrm{H} \cdots \mathrm{S}$ intermolecular hydrogen bond with another. $\mathrm{BipyH}^{+}$cations in (1), as well as $\mathrm{PhenH}^{+}$in (2), are not directly connected to each other (Fig. 2). The Detba ${ }^{-}$anions in (2) do not form dimers, unlike barbiturate and thiobarbiturate ions in the corresponding phenanthrolinium salts [5]. Each chain of two water molecules is bound by hydrogen bonds $\mathrm{OW}-\mathrm{HW} \cdots \mathrm{O}$ with three Detba ${ }^{-}$anions, which in turn are connected with to the $\mathrm{PhenH}^{+}$cations by the $\mathrm{N}-\mathrm{H} \cdots \mathrm{O}, \mathrm{C}-\mathrm{H} \cdots \mathrm{S}$ hydrogen bonds. The $\mathrm{C}-$ $\mathrm{H} \cdots \mathrm{X}(\mathrm{X}=\mathrm{O}, \mathrm{S})$ weak hydrogen bonds exert a significant influence on the supramolecular architecture of the compounds. The compound (2) has a new topology of 3D net.

Several types of $\pi-\pi$ interactions between the rings are found in the (1)-(2) (Fig. 2S). Co-crystal of (1) melts at $110.3^{\circ} \mathrm{C}$ and salt (2) is dehydrated in the range of $70-135^{\circ} \mathrm{C}$, a further increase in temperature leads to their oxidative decomposition.

\section{Supplementary data}

The crystallographic data (excluding structure factors) for the structural analysis have been deposited with Cambridge Crystallographic Data Centre ((1) - CCDC \# ????; (2) CCDC \# ????). The information may be obtained free of charge from The Director, CCDC, 12 Union Road, Cambridge CB2 1EZ, UK (Fax: +44(1223)336-033, E-mail: deposit@ccdc.cam.ac.uk, or www: www.ccdc.cam.ac.uk). 


\section{Acknowledgements}

The study was carried out within the public task of the Ministry of Education and Science of the Russian Federation to the Siberian Federal University (4.7666.2017/BP) in 2017-2019. X-ray data from single crystals were obtained with use the analytical equipment of Baikal Center of collective use of SB RAS and with use the analytical equipment of Krasnoyarsk Center of collective use of SB RAS. 


\section{References}

1. Bondock, S. Tarhoni A. E.,. Fadda A. A. //Phosphorus Sulfur Silicon Relat. Elem. 2007. - Vol. 182. - P. 1915 - 1936.

2. Mahmudov, K. T. Barbituric acids as a useful tool for the construction of coordination and supramolecular compounds / K. T. Mahmudov, M. N. Kopylovich, A. M. Maharramov et al. //Coord. Chem. Rev. - 2014. - Vol. 265. - P. 1-37.

3. El-Gahani, M. A. Reactivity of five-coordinate $\mathrm{Co}(\mathrm{II}), \mathrm{Ni}(\mathrm{II})$ and $\mathrm{Cu}$ (II) chelates towards thiobarbituric acid as a sulfur donor ligand and their antimicrobial activities / M. A. El-Gahani, Ibrahim S.A., H. M. A. Salman // Synth. React. Inorg. Met.-Org. Chem. - 1991. - Vol. 21., N 10. - P. 1497-1509.

4. Balas V. I. Synthesis, structural characterization and biological studies of the triphenyltin (IV) complex with 2-thiobarbituric acid / V. I. Balas, I. I. Verginadi, G. D Geromichalos et al.//Eur. J. Med. Chem. - 2011. - Vol. 46. - №. 7. - P. 2835-2844.

5. Ivanova B.B., Spiteller M. Cryst. Growth Des. 2010, V.10. P.2470-2474.

6. Pan, Z.R.Synthesis, structure and nonlinear optical properties of three dimensional compounds / Z. R. Pan, Y. C. Zhang, Y. L. Song et al.// J. Coord. Chem. - 2008. - Vol. 61, N. 20. - P. $3189-$ 3199

7. Gryl M. Acta Cryst. 2015. B71. P. 392-405.

8. Cambridge Structural Database. Cambridge (UK): Univ. of Cambridge, 2017.

9. Головнев Н.Н., Молокеев М.С. 2-тиобарбитуровая кислота и ее комплексы с металлами: синтез, структура и свойства. Красноярск: Сиб. федер. ун-т, 2014. 252 с.

10. Munchow E., Valente L.L. Peralta S.L., Fernandez M.R., Lima G.S., Petzhold C.L., Piva E., Ogliari F.A. //J. Biomed. Mater. Res. B. 2013 doi: 10.1002/jbm.b.32933]

11. Rustemeier K., Demetriou D., Schepers G., Voncken P. // J. Chromatogr. 613 (1993) 95-103.

12. Domagalska B.W., Wilk K.A., Szymusiak H., Zielinski R. // Computers Chem. 24 (2000 359-367.

13. Sni Y., Mikosch A., Winzenberg K.N., Kemppinen P., Easton C.D., Bilic A., Forsyth C.M., Dunn C.J., Singh Th.B.,Collis G.E.// J. Mater. Chem. C. 2014. 2. 3895-3899.

14. [Steed].

15. Braun D.E., Raabe K., Schneeberger A., Kahlenberg V., GriesserU.J. Molecules. 2017. 22. 2238-2257].

16. Z.-X. Chang, Li Y., Li K.-C., Song W.-D, Li Q.-S. // Inorg. Chem. Commun. 2007. 10. N

11. P.1276-1280.

17. H. L.C. Feltham, S. Brooker. // Coord. Chem. Rev. 276 (2014) 1-33. 
18. Molokeev M.S., Golovnev N.N., Vereshchagin S.N., Atuchin V.V. // Polyhedron. 2015. V. 98. P. 113-119.

19. Golovnev N.N., Molokeev M.S., Vereshchagin S.N., Sterkhova I. V., Atuchin V.V. // Polyhedron. 2015. V. 85. P. 493-498.

20. Golovnev. N.N., Molokeev M.S., Lutoshkin M.A. // Russ. J. Inorg. Chem. 2015. V. 60. № 5. P. 572. $\mathrm{Ag}$

21. Golovnev N.N., Molokeev M.S. Golovneva I.I. //Russ. J. Coord. Chem. 2015. V. 41. № 5. P. 300-304. $\mathrm{Pb}$

22. Golovnev, N.N., M.S. Molokeev, M.K. Lesnikov, Atuchin V. V. // Chem. Phys. Lett. - 2016. - Vol. 653. - P. 54-59. [M $\left.\left(\mathrm{H}_{2} \mathrm{O}\right)_{6}\right](1,3 \text {-diethyl-2-thiobarbiturate })_{2} \cdot 2 \mathrm{H}_{2} \mathrm{O}$

23. Golovnev, N. N., M. S. Molokeev, A. S. Samoilo, Atuchin V.V. / J. Coord. Chem. - 2016. Vol. 69, N 6. - C. 957-965. $\mathrm{M}\left(\mathrm{H}_{2} \mathrm{O}\right)_{2}$ (1, 3-diethyl-2-thiobarbiturate $)_{2} \mathrm{M}=\mathrm{Ca}^{2+}, \mathrm{Sr}^{2+}$

24. Golovnev, N. N., M. S. Molokeev, S. N. Vereshchagin // Russ. J. Coord. Chem. - 2016. Vol. 57, N 1. - P. 167-174. europium (III)

25 Golovnev N. N., Molokeev M. S., Smolentsev A. I., Lesnikov M. K. // Russ. J. Coord. Chem. 2017. V. 43. № 2. P. 82-85. $\mathrm{Co}_{2}(\mathrm{Bu})_{4}(\mathrm{Hdetba})_{2}$

26. Golovnev N. N., Molokeev M. S., Sterkhova I. V., Lesnikov M. K., Atuchin V. V. // Polyhedron. 2017. V. 134. P. 120-125. Mn

27. [SHELX]. G.M. Sheldrick, Acta Cryst. A, 2008, 64, 112-122.

28. [PLATON]. PLATON - A Multipurpose Crystallographic Tool. Utrecht University, Utrecht, The Netherlands, 2008.

29. [DIAMOND]. K. Brandenburg, M. Berndt, DIAMOND - Visual Crystal Structure Information System CRYSTAL IMPACT, Postfach 1251, D-53002 Bonn

30. [TOPAS]. Bruker AXS TOPAS V4: General profile and structure analysis software for powder diffraction data. - User's Manual, Bruker AXS, Karlsruhe, Germany, 2008.

31. Sharkar M., Kam K., Reddy M. // Indian. J. Chem. 1989, 28A, 437.

32. Lutoshkin M. A., Petrov A.I., Golovnev N. N. // J. Solution Chem. 2016. V. 45. N 10. P. 1453-1467.

33. S. L. Childs, P. Stahly, A. Park, Mol. Pharmaceutics, 2007, 4(3), 323.

34. Cherukuvada, R. Kaur, T. N. G. Row, CrystEngComm., 2016. DOI: 10.1039/c6ce1835a]. 35. F.E. Kuhn, M. Groarke, E. Bencze, E. Herdtweck, A. Prazeres, A.M. Santos, M.J. Calhorda, C.C. Roma, I.S. GonÁalves, A.D. Lopes, M. Pillinger. Chem. Eur. J. 2002, 8, No.10. P. 23702383 .

36. Howard, S. T. J. Am. Chem. Soc. 1996.118 (42), 10269-10274

37. Ma G., Ilyukhin A., Glaser J. Cryst. Struct. 2000. C56. 1473-1475 
38. An B., Bay Y., Yang F.Z. // Z. Naturforsch. 2012. 67B. 85-88.

39. Kadarkaraisamy M., Engelhart D.P., Basa P.N., Sykes A.G. // J. Coord. Chem. 2010. 63(13) 2261-2267

40. R.D. Gillard, M. B. Hursthouse, K.M. A. Malik, S. Paisey J. Chem. Cryst. V.28, No.8, 1998. p. 611-618

41. Головнев Н. Н., Молокеев М. С., Стерхова И.В., Головнева И.И.. Структура ионных со-кристаллов 2-тиобарбитурат пиперидиния -2-тиобарбитуровая кислота // Журнал 42. структурной химии. 2016. Т. 57. № 6. С. 1308-1311.

42. Vishweshwar P., Nangia A., Lynch. V.M. // Chem. Commun. - 2001. - P.179-180 DOI:

$10.1039 / \mathrm{b} 007346 \mathrm{f}]$

43. Hensen K., Spangenberg B., Bolte M. Cryst. Struct. 2000. C56. 208-210.

44. Athimoolam S., Natarajan S. (2007). Acta Cryst. C63, o263-o266.

\section{Graphical Abstract}


Table 1. Crystal structure parameters of (1) and (2)

\begin{tabular}{|c|c|c|}
\hline Single crystal & BipyH(Detba)(HDetba) (1) & PhenH(Detba) $\cdot \mathrm{H}_{2} \mathrm{O}(\mathbf{2})$ \\
\hline Moiety formula & $\mathrm{C}_{26} \mathrm{H}_{32} \mathrm{~N}_{6} \mathrm{O}_{4} \mathrm{~S}_{2}$ & $\mathrm{C}_{20} \mathrm{H}_{22} \mathrm{~N}_{4} \mathrm{O}_{3} \mathrm{~S}$ \\
\hline Dimension (mm) & $0.40 \times 0.31 \times 0.18$ & $0.34 \times 0.31 \times 0.15$ \\
\hline Color & Yellow & Yellow \\
\hline Molecular weight & 556.69 & 398.48 \\
\hline Temperature $(\mathrm{K})$ & 100 & 100 \\
\hline Space group, $Z$ & $P-1,2$ & $P-1,4$ \\
\hline$a(\AA)$ & $10.1936(6)$ & $10.9194(9)$ \\
\hline$b(\AA)$ & $11.0122(6)$ & $13.351(1)$ \\
\hline$c(\AA)$ & $13.4505(8)$ & $13.8901(11)$ \\
\hline$\alpha\left(^{(o}\right)$ & $68.875(2)$ & $104.723(3)$ \\
\hline$\beta\left(^{\mathrm{o}}\right)$ & $87.388(2)$ & $101.020(3)$ \\
\hline$\gamma\left({ }^{\circ}\right)$ & $72.767(2)$ & $99.626(3)$ \\
\hline$V\left(\AA^{3}\right)$ & $1342.00(14)$ & $1872.1(3)$ \\
\hline$\rho_{\text {calc }}\left(\mathrm{g} / \mathrm{cm}^{3}\right)$ & 1.378 & 1.414 \\
\hline$\mu\left(\mathrm{mm}^{-1}\right)$ & 0.243 & 0.203 \\
\hline $\begin{array}{l}\text { Reflections } \\
\text { measured }\end{array}$ & 57298 & 90030 \\
\hline $\begin{array}{l}\text { Reflections } \\
\text { independent }\end{array}$ & 7863 & 10998 \\
\hline $\begin{array}{l}\text { Reflections with } F \\
\quad>4 \sigma(F)\end{array}$ & 6564 & 7730 \\
\hline $2 \theta_{\max }\left({ }^{\circ}\right)$ & 60.15 & 60.16 \\
\hline$h, k, l$ - limits & $\begin{array}{c}-14 \leq h \leq 14 \\
-15 \leq k \leq 15 \\
-18 \leq l \leq 18\end{array}$ & $\begin{array}{c}-15 \leq h \leq 15 \\
-18 \leq k \leq 19 \\
-19 \leq l \leq 19\end{array}$ \\
\hline$R_{\text {int }}$ & 0.0381 & 0.0775 \\
\hline $\begin{array}{l}\text { The weighed } \\
\text { refinement of } F^{2}\end{array}$ & $\begin{array}{l}w=1 /\left[\sigma^{2}\left(F_{\mathrm{o}}^{2}\right)+(0.0385 P)^{2}+0.6\right. \\
513 \mathrm{P}]\end{array}$ & $w=1 /\left[\sigma^{2}\left(F_{\mathrm{o}}^{2}\right)+(0.056 P)^{2}+0.744 \mathrm{P}\right]$ \\
\hline $\begin{array}{l}\text { Number of } \\
\text { refinement } \\
\text { parameters }\end{array}$ & 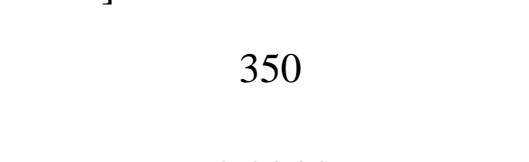 & 521 \\
\hline$R 1\left[F_{\mathrm{o}}>4 \sigma\left(F_{\mathrm{o}}\right)\right]$ & 0.0344 & 0.0493 \\
\hline$w R 2$ & 0.0891 & 0.1241 \\
\hline Goof & 1.017 & 1.036 \\
\hline$\Delta \rho_{\max }\left(\mathrm{e} / \AA^{3}\right)$ & 0.382 & 0.893 \\
\hline$\Delta \rho_{\min }\left(\mathrm{e} / \AA^{3}\right)$ & -0.359 & -0.406 \\
\hline$(\Delta / \sigma)_{\max }$ & 0.001 & 0.404 \\
\hline
\end{tabular}


Table 2. Hydrogen-bond geometry in (1) and (2) structures $\left(\AA{ }^{\circ}{ }^{\circ}\right)$.

\begin{tabular}{|c|c|c|c|c|c|c|}
\hline $\mathrm{D}-\mathrm{H}$ & $\mathrm{d}(\mathrm{D}-\mathrm{H})$ & $\mathrm{d}(\mathrm{H} \cdots \mathrm{A})$ & $\begin{array}{l}\angle \mathrm{D}- \\
\mathrm{H} \cdots \mathrm{A}\end{array}$ & $\mathrm{D} \cdots \mathrm{A}$ & A & $\begin{array}{c}\text { Transformation } \\
\text { for A atom }\end{array}$ \\
\hline \multicolumn{7}{|c|}{ BipyH(Detba)(HDetba) (1) } \\
\hline $\mathrm{N} 2 \mathrm{C}-\mathrm{H} 2 \mathrm{C}$ & 0.86 & 1.91 & 142 & $2.6395(14)$ & O1B & $\mathrm{x}, \mathrm{y}, \mathrm{z}$ \\
\hline $\mathrm{C} 6 \mathrm{C}-\mathrm{H} 6 \mathrm{C}$ & 0.93 & 2.39 & 163 & $3.2923(17)$ & O1A & $\mathrm{x}, \mathrm{y}, 1+\mathrm{z}$ \\
\hline $\mathrm{C} 9 \mathrm{C}-\mathrm{H} 9 \mathrm{~B}$ & 0.93 & 2.53 & 168 & $3.4411(15)$ & O1A & $\mathrm{x}, \mathrm{y}, 1+\mathrm{z}$ \\
\hline $\mathrm{C} 4 \mathrm{C}-\mathrm{H} 4 \mathrm{C}$ & 0.93 & 2.76 & 171 & $3.6822(14)$ & S1 & $1+\mathrm{x},-1+\mathrm{y}, 1+\mathrm{z}$ \\
\hline $\mathrm{C} 5 \mathrm{~A}-\mathrm{H} 5 \mathrm{~A}$ & 0.93 & $2.6486(7)$ & $121.47(8)$ & $3.233(1)$ & $\mathrm{O} 2 \mathrm{~B}$ & $\mathrm{x}, \mathrm{y}, \mathrm{z}$ \\
\hline $\mathrm{O} 2 \mathrm{~A}-\mathrm{H} 1 \mathrm{~A}$ & $1.12(2)$ & $1.32(2)$ & $178(2)$ & $2.440(1)$ & $\mathrm{O} 2 \mathrm{~B}$ & $\mathrm{x}, \mathrm{y}, \mathrm{z}$ \\
\hline \multicolumn{7}{|c|}{ PhenH(Detba) $\cdot \mathrm{H}_{2} \mathrm{O}(\mathbf{2})$} \\
\hline $\mathrm{N} 1 \mathrm{~A}-\mathrm{H} 1 \mathrm{~A}$ & 0.86 & 1.94 & 142 & $2.671(2)$ & $\mathrm{O} 2 \mathrm{D}$ & $\mathrm{x}, \mathrm{y}, \mathrm{z}$ \\
\hline $\mathrm{N} 1 \mathrm{~B}-\mathrm{H} 1 \mathrm{~B}$ & 0.86 & 1.96 & 139 & $2.674(2)$ & $\mathrm{O} 2 \mathrm{C}$ & $\mathrm{x}, \mathrm{y}, \mathrm{z}$ \\
\hline $\mathrm{O} 1 \mathrm{~W}-\mathrm{H} 1 \mathrm{WA}$ & $0.90(2)$ & $1.94(2)$ & $163(2)$ & $2.809(2)$ & $\mathrm{O} 2 \mathrm{C}$ & $\mathrm{x}, \mathrm{y}, \mathrm{z}$ \\
\hline $\mathrm{O} 1 \mathrm{~W}-\mathrm{H} 1 \mathrm{WB}$ & $0.83(2)$ & $2.11(2)$ & $154(2)$ & $2.876(2)$ & O1D & $1-\mathrm{x}, 1-\mathrm{y}, 1-\mathrm{z}$ \\
\hline $\mathrm{O} 2 \mathrm{~W}-\mathrm{H} 2 \mathrm{WA}$ & $1.05(2)$ & $1.82(2)$ & $168(2)$ & $2.854(2)$ & $\mathrm{O} 1 \mathrm{~W}$ & $\mathrm{x}, \mathrm{y}, \mathrm{z}$ \\
\hline $\mathrm{O} 2 \mathrm{~W}-\mathrm{H} 2 \mathrm{WB}$ & $1.05(2)$ & $1.79(2)$ & $170(2)$ & $2.827(2)$ & $\mathrm{O} 2 \mathrm{D}$ & $\mathrm{x}, \mathrm{y}, \mathrm{z}$ \\
\hline $\mathrm{C} 12 \mathrm{~B}-\mathrm{H} 12 \mathrm{~B}$ & 0.93 & 2.20 & 142 & $2.992(2)$ & $\mathrm{O} 1 \mathrm{C}$ & $1-x, 2-y, 2-z$ \\
\hline $\mathrm{C} 10 \mathrm{~A}-\mathrm{H} 10 \mathrm{~A}$ & 0.93 & 2.84 & 145 & $3.639(2)$ & $\mathrm{S} 2$ & $\mathrm{x}, 1+\mathrm{y}, \mathrm{z}$ \\
\hline $\mathrm{C} 12 \mathrm{~A}-\mathrm{H} 12 \mathrm{~A}$ & 0.93 & 2.39 & 126 & $3.030(2)$ & O1D & $1-x, 1-y, 1-z$ \\
\hline
\end{tabular}




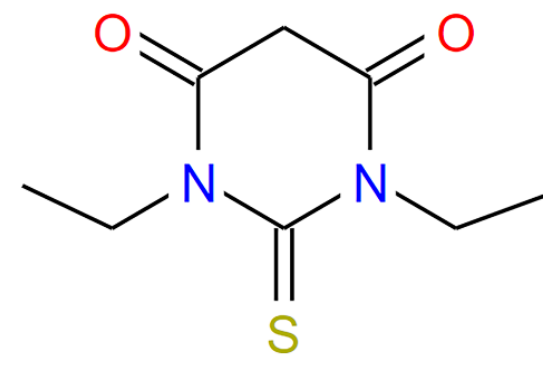

Fig. 1. Graphical formulas of 1,3-Diethyl-2-thiobarbituric acid (HDetba)

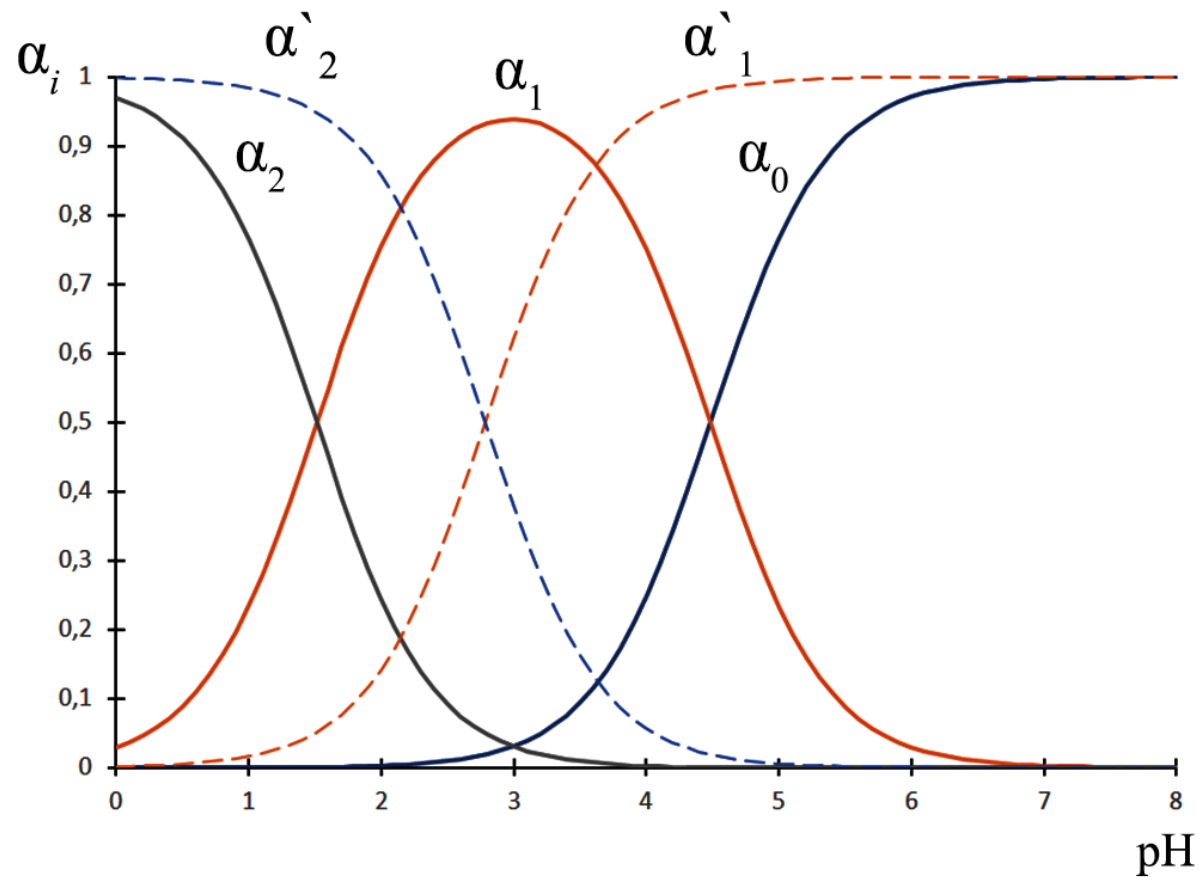

Fig. 2. HDetba and Bipy distribution diagram of species: $\alpha_{0}-\mathrm{Bipy}, \alpha_{1}-\mathrm{BipyH}^{+}, \alpha_{2}-\mathrm{BipyH}_{2}{ }^{2+}$ $; \alpha_{2}-$ HDetba, $\alpha_{1}-$ Detba $^{-}$. Here $\alpha i$ is the molar fraction of the $\mathrm{i}$-th species. 


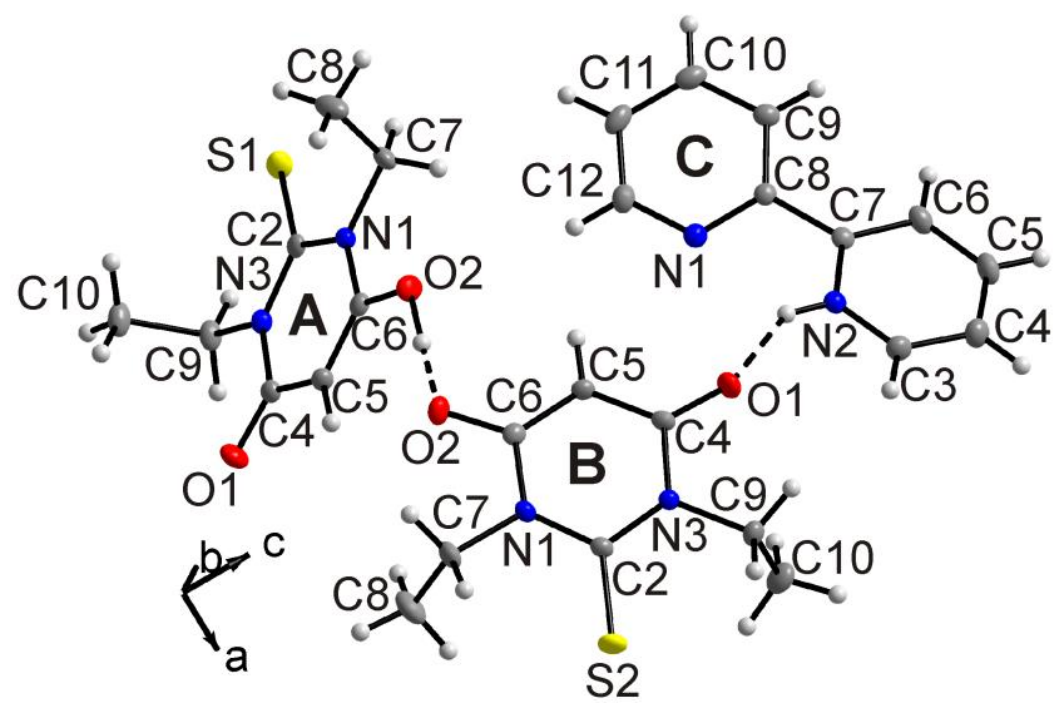

a)

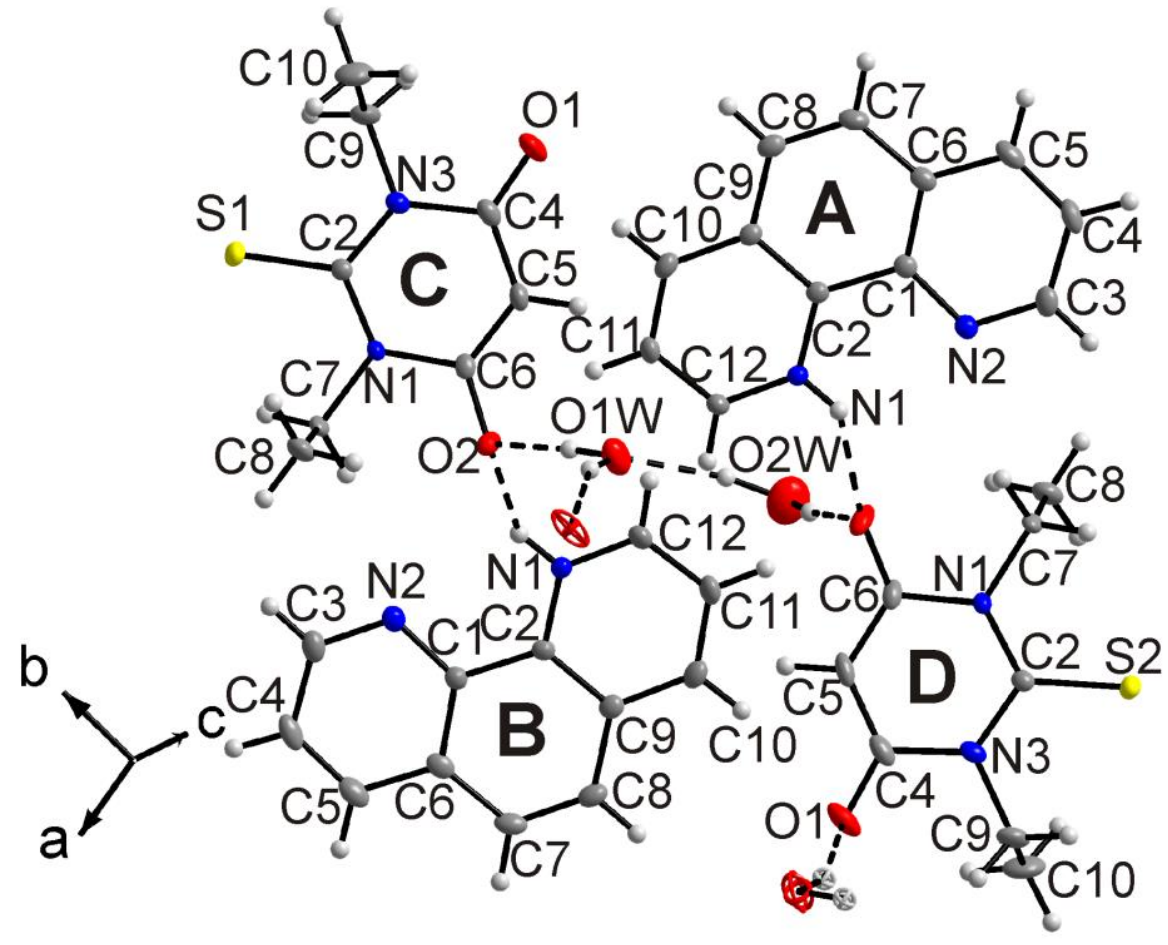

b)

Fig. 3. The asymmetric unit of the (1) (a), (2) (b) unit cell. Symmetry independent, different molecules are marked by A, B, C, D labels. All atoms in the asymmetric unit are labeled. The neighboring symmetry-generated atoms are represented by principal ellipses with an individual color. The intermolecular hydrogen bonds are represented by dashed lines. The ellipsoids are drawn at the $50 \%$ probability level, except for the hydrogen atoms represented by spheres. 


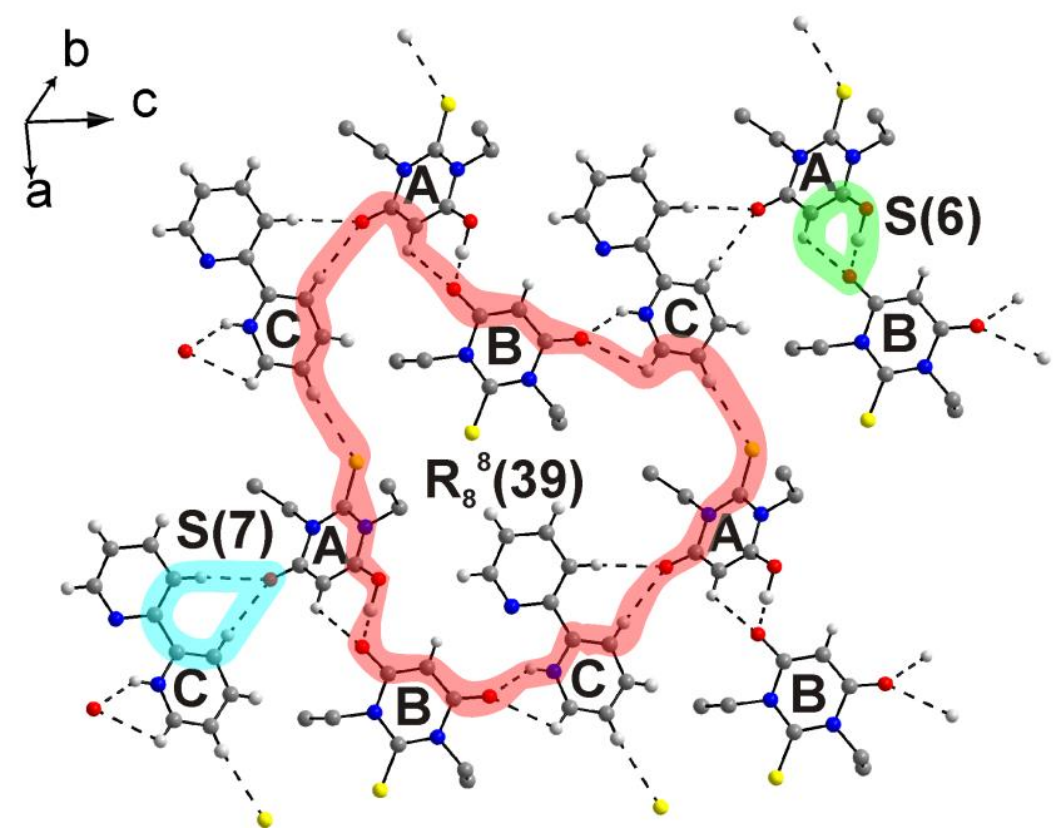

a)

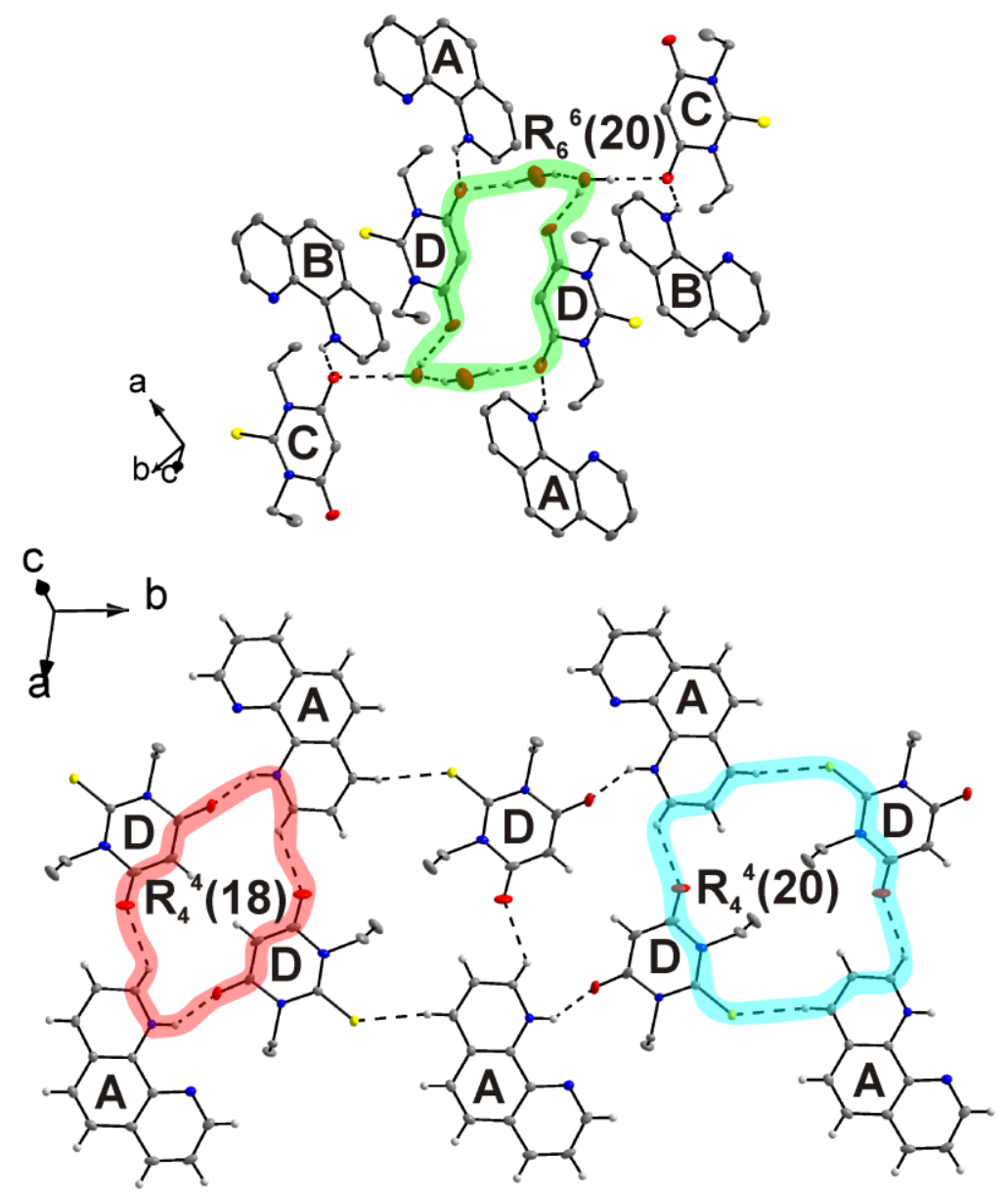

b) 
Fig. 4. Hydrogen bonding in (1) (a) and (2) (b). The H-bonds are marked by dashed lines, the Hbond motifs are marked by circles. Different ions/molecules are marked by A, B, C, D labels. Some $\mathrm{H}$ atoms were deleted to simplify the figure. 


\section{Supported Information}

Table 1S. Main parameters of processing and refinement of the (1) and (2) samples

\begin{tabular}{cc}
\hline Compound & BipyH(Detba)(HDetba) (1) \\
\hline Sp.Gr. & $P-1$ \\
$a, \AA$ & $10.381(2)$ \\
$b, \AA$ & $11.070(2)$ \\
$c, \AA$ & $13.581(3)$ \\
$\alpha,^{\circ}$ & $69.175(6)$ \\
$\beta,^{\circ}$ & $87.72(1)$ \\
$\gamma^{\circ}{ }^{\circ}$ & $72.358(9)$ \\
$V, \AA^{3}$ & $1386.1(4)$ \\
$2 \theta$-interval, & $5-85$ \\
$R_{w p}, \%$ & 6.84 \\
$R_{p}, \%$ & 5.25 \\
$R_{\text {exp }}, \%$ & 4.49 \\
$\chi^{2}$ & 1.53 \\
\hline
\end{tabular}


Table 2S. Main geometric parameters $\left(\AA,^{\circ}\right)$ of (1) and (2)

\begin{tabular}{|c|c|c|c|}
\hline \multicolumn{2}{|c|}{ BipyH(Detba)(HDetba) (1) } & \multicolumn{2}{|c|}{ PhenH(Detba) $\cdot \mathrm{H}_{2} \mathrm{O}(\mathbf{2})$} \\
\hline $\mathrm{S} 1-\mathrm{C} 2 \mathrm{~A}$ & $1.6801(11)$ & $\mathrm{S} 1-\mathrm{C} 2 \mathrm{C}$ & $1.6882(16)$ \\
\hline $\mathrm{S} 2-\mathrm{C} 2 \mathrm{~B}$ & $1.6769(11)$ & $\mathrm{S} 2-\mathrm{C} 2 \mathrm{D}$ & $1.6841(17)$ \\
\hline $\mathrm{O} 1 \mathrm{~A}-\mathrm{C} 4 \mathrm{~A}$ & $1.2390(15)$ & $\mathrm{O} 1 \mathrm{C}-\mathrm{C} 4 \mathrm{C}$ & $1.234(2)$ \\
\hline $\mathrm{O} 1 \mathrm{~B}-\mathrm{C} 4 \mathrm{~B}$ & $1.2439(17)$ & $\mathrm{O} 1 \mathrm{D}-\mathrm{C} 4 \mathrm{D}$ & $1.249(2)$ \\
\hline $\mathrm{O} 2 \mathrm{~A}-\mathrm{C} 6 \mathrm{~A}$ & $1.3040(13)$ & $\mathrm{O} 2 \mathrm{C}-\mathrm{C} 6 \mathrm{C}$ & $1.271(2)$ \\
\hline $\mathrm{O} 2 \mathrm{~B}-\mathrm{C} 6 \mathrm{~B}$ & $1.2841(13)$ & $\mathrm{O} 2 \mathrm{D}-\mathrm{C} 6 \mathrm{D}$ & $1.257(2)$ \\
\hline $\mathrm{N} 1 \mathrm{~A}-\mathrm{C} 2 \mathrm{~A}$ & $1.3765(13)$ & $\mathrm{N} 1 \mathrm{C}-\mathrm{C} 2 \mathrm{C}$ & $1.372(2)$ \\
\hline $\mathrm{N} 1 \mathrm{~B}-\mathrm{C} 2 \mathrm{~B}$ & $1.3731(13)$ & $\mathrm{N} 1 \mathrm{D}-\mathrm{C} 2 \mathrm{D}$ & $1.368(2)$ \\
\hline $\mathrm{N} 1 \mathrm{~A}-\mathrm{C} 6 \mathrm{~A}$ & $1.3932(14)$ & $\mathrm{N} 1 \mathrm{C}-\mathrm{C} 6 \mathrm{C}$ & $1.421(2)$ \\
\hline $\mathrm{N} 1 \mathrm{~B}-\mathrm{C} 6 \mathrm{~B}$ & $1.4021(13)$ & $\mathrm{N} 1 \mathrm{D}-\mathrm{C} 6 \mathrm{D}$ & $1.416(2)$ \\
\hline N1A-C7A & $1.4793(15)$ & $\mathrm{N} 1 \mathrm{C}-\mathrm{C} 7 \mathrm{C}$ & $1.478(2)$ \\
\hline $\mathrm{N} 1 \mathrm{~B}-\mathrm{C} 7 \mathrm{~B}$ & $1.4823(18)$ & N1D $-C 7 D$ & $1.476(2)$ \\
\hline $\mathrm{N} 3 \mathrm{~A}-\mathrm{C} 2 \mathrm{~A}$ & $1.3686(14)$ & $\mathrm{N} 3 \mathrm{C}-\mathrm{C} 2 \mathrm{C}$ & $1.363(2)$ \\
\hline $\mathrm{N} 3 \mathrm{~B}-\mathrm{C} 2 \mathrm{~B}$ & $1.3710(16)$ & $\mathrm{N} 3 \mathrm{D}-\mathrm{C} 2 \mathrm{D}$ & $1.366(2)$ \\
\hline $\mathrm{N} 3 \mathrm{~A}-\mathrm{C} 4 \mathrm{~A}$ & $1.4226(14)$ & $\mathrm{N} 3 \mathrm{C}-\mathrm{C} 4 \mathrm{C}$ & $1.436(2)$ \\
\hline $\mathrm{N} 3 \mathrm{~B}-\mathrm{C} 4 \mathrm{~B}$ & $1.4170(14)$ & $\mathrm{N} 3 \mathrm{D}-\mathrm{C} 4 \mathrm{D}$ & $1.424(2)$ \\
\hline $\mathrm{N} 3 \mathrm{~A}-\mathrm{C} 9 \mathrm{~A}$ & $1.4766(14)$ & $\mathrm{N} 3 \mathrm{C}-\mathrm{C} 9 \mathrm{C}$ & $1.475(2)$ \\
\hline $\mathrm{N} 3 \mathrm{~B}-\mathrm{C} 9 \mathrm{~B}$ & $1.4750(14)$ & $\mathrm{N} 3 \mathrm{D}-\mathrm{C} 9 \mathrm{D}$ & $1.476(2)$ \\
\hline $\mathrm{C} 4 \mathrm{~A}-\mathrm{C} 5 \mathrm{~A}$ & $1.4094(14)$ & $\mathrm{C} 4 \mathrm{C}-\mathrm{C} 5 \mathrm{C}$ & $1.403(2)$ \\
\hline $\mathrm{C} 4 \mathrm{~B}-\mathrm{C} 5 \mathrm{~B}$ & $1.4014(14)$ & $\mathrm{C} 4 \mathrm{D}-\mathrm{C} 5 \mathrm{D}$ & $1.388(3)$ \\
\hline $\mathrm{C} 5 \mathrm{~A}-\mathrm{C} 6 \mathrm{~A}$ & $1.3666(17)$ & $\mathrm{C} 5 \mathrm{C}-\mathrm{C} 6 \mathrm{C}$ & $1.374(2)$ \\
\hline $\mathrm{C} 5 \mathrm{~B}-\mathrm{C} 6 \mathrm{~B}$ & $1.3770(18)$ & C5D-C6D & $1.391(3)$ \\
\hline $\mathrm{C} 7 \mathrm{~A}-\mathrm{C} 8 \mathrm{~A}$ & $1.517(2)$ & $\mathrm{C} 7 \mathrm{C}-\mathrm{C} 8 \mathrm{C}$ & $1.511(2)$ \\
\hline $\mathrm{C} 7 \mathrm{~B}-\mathrm{C} 8 \mathrm{~B}$ & $1.517(2)$ & $\mathrm{C} 7 \mathrm{D}-\mathrm{C} 8 \mathrm{D}$ & $1.516(2)$ \\
\hline $\mathrm{C} 9 \mathrm{~A}-\mathrm{C} 10 \mathrm{~A}$ & $1.521(2)$ & $\mathrm{C} 9 \mathrm{C}-\mathrm{C} 10 \mathrm{C}$ & $1.521(3)$ \\
\hline $\mathrm{C} 9 \mathrm{~B}-\mathrm{C} 10 \mathrm{~B}$ & $1.520(2)$ & C9D - C10D & $1.514(3)$ \\
\hline $\mathrm{C} 2 \mathrm{~A}-\mathrm{N} 1 \mathrm{~A}-\mathrm{C} 6 \mathrm{~A}$ & $121.9(1)$ & $\mathrm{C} 2 \mathrm{C}-\mathrm{N} 1 \mathrm{C}-\mathrm{C} 6 \mathrm{C}$ & $123.0(1)$ \\
\hline $\mathrm{C} 2 \mathrm{~B}-\mathrm{N} 1 \mathrm{~B}-\mathrm{C} 6 \mathrm{~B}$ & $122.7(1)$ & $\mathrm{C} 2 \mathrm{D}-\mathrm{N} 1 \mathrm{D}-\mathrm{C} 6 \mathrm{D}$ & $123.0(1)$ \\
\hline
\end{tabular}




\begin{tabular}{|c|c|c|c|}
\hline $\mathrm{N} 1 \mathrm{~A}-\mathrm{C} 2 \mathrm{~A}-\mathrm{N} 3 \mathrm{~A}$ & $116.90(9)$ & $\mathrm{N} 1 \mathrm{C}-\mathrm{C} 2 \mathrm{C}-\mathrm{N} 3 \mathrm{C}$ & $117.0(1)$ \\
$\mathrm{N} 1 \mathrm{~B}-\mathrm{C} 2 \mathrm{~B}-\mathrm{N} 3 \mathrm{~B}$ & $116.56(9)$ & $\mathrm{N} 1 \mathrm{D}-\mathrm{C} 2 \mathrm{D}-\mathrm{N} 3 \mathrm{D}$ & $117.4(1)$ \\
\hline $\mathrm{N} 3 \mathrm{~A}-\mathrm{C} 2 \mathrm{~A}-\mathrm{S} 1$ & $121.95(9)$ & $\mathrm{N} 3 \mathrm{C}-\mathrm{C} 2 \mathrm{C}-\mathrm{S} 1$ & $121.9(1)$ \\
$\mathrm{N} 3 \mathrm{~B}-\mathrm{C} 2 \mathrm{~B}-\mathrm{S} 2$ & $121.83(9)$ & $\mathrm{N} 3 \mathrm{D}-\mathrm{C} 2 \mathrm{D}-\mathrm{S} 2$ & $121.4(1)$ \\
\hline $\mathrm{C} 2 \mathrm{~A}-\mathrm{N} 3 \mathrm{~A}-\mathrm{C} 4 \mathrm{~A}$ & $124.3(1)$ & $\mathrm{C} 2 \mathrm{C}-\mathrm{N} 3 \mathrm{C}-\mathrm{C} 4 \mathrm{C}$ & $124.1(1)$ \\
$\mathrm{C} 2 \mathrm{~B}-\mathrm{N} 3 \mathrm{~B}-\mathrm{C} 4 \mathrm{~B}$ & $124.0(1)$ & $\mathrm{C} 2 \mathrm{D}-\mathrm{N} 3 \mathrm{D}-\mathrm{C} 4 \mathrm{D}$ & $123.7(1)$ \\
\hline $\mathrm{N} 1 \mathrm{~A}-\mathrm{C} 2 \mathrm{~A}-\mathrm{S} 1$ & $121.16(9)$ & $\mathrm{N} 1 \mathrm{C}-\mathrm{C} 2 \mathrm{C}-\mathrm{S} 1$ & $121.1(1)$ \\
$\mathrm{N} 1 \mathrm{~B}-\mathrm{C} 2 \mathrm{~B}-\mathrm{S} 2$ & $121.61(9)$ & $\mathrm{N} 1 \mathrm{D}-\mathrm{C} 2 \mathrm{D}-\mathrm{S} 2$ & $121.2(1)$ \\
\hline $\mathrm{C} 4 \mathrm{~A}-\mathrm{C} 5 \mathrm{~A}-\mathrm{C} 6 \mathrm{~A}$ & $121.1(1)$ & $\mathrm{C} 4 \mathrm{C}-\mathrm{C} 5 \mathrm{C}-\mathrm{C} 6 \mathrm{C}$ & $122.60(15)$ \\
$\mathrm{C} 4 \mathrm{~B}-\mathrm{C} 5 \mathrm{~B}-\mathrm{C} 6 \mathrm{~B}$ & $121.2(1)$ & $\mathrm{C} 4 \mathrm{D}-\mathrm{C} 5 \mathrm{D}-\mathrm{C} 6 \mathrm{D}$ & $122.76(15)$ \\
\hline
\end{tabular}


Table 3S. Parameters of the $\pi-\pi$ interaction in (1) and (2)

\begin{tabular}{|c|c|c|c|c|c|c|}
\hline $\mathrm{Cg}_{\mathrm{i}}-\mathrm{Cg}_{\mathrm{j}}$ & $\mathrm{d}(\mathrm{Cg}-\mathrm{Cg}), \AA$ & $\alpha, \operatorname{deg}$ & $\beta, \operatorname{deg}$ & $\gamma, \operatorname{deg}$ & Cg $g_{i} \_p, \AA$ & Shift, $\AA$ \\
\hline \multicolumn{7}{|c|}{ BipyH(Detba)(HDetba) (1) } \\
\hline $\mathrm{Cg}_{1}-\mathrm{Cg}_{1}^{\prime}$ & $3.7393(7)$ & $0.02(5)$ & 25.6 & 25.6 & $3.3726(4)$ & 1.615 \\
\hline $\mathrm{Cg}_{3}-\mathrm{Cg}_{3}^{\prime}$ & $3.5819(7)$ & $0.00(6)$ & 22.4 & 22.4 & $3.3125(5)$ & 1.363 \\
\hline $\mathrm{Cg}_{2}-\mathrm{Cg}^{\prime \prime}{ }_{3}$ & $3.4250(7)$ & $2.62(6)$ & 14.9 & 15.7 & $3.2980(4)$ & 0.924 \\
\hline \multicolumn{7}{|c|}{ PhenH(Detba) $\cdot \mathrm{H}_{2} \mathrm{O}(2)$} \\
\hline $\mathrm{Cg}_{1}-\mathrm{Cg}^{\prime}{ }_{5}$ & $3.7941(9)$ & $4.24(7)$ & 25.3 & 28.3 & $3.3409(6)$ & 1.798 \\
\hline $\mathrm{Cg}_{2}-\mathrm{Cg}_{4}^{\prime}$ & $3.7930(9)$ & $5.36(7)$ & 29.5 & 24.9 & $3.4393(6)$ & 1.599 \\
\hline $\mathrm{Cg}_{2}-\mathrm{Cg}_{6}^{\prime}$ & $3.6049(9)$ & $1.70(7)$ & 21.4 & 20.0 & $3.3883(6)$ & 1.231 \\
\hline $\mathrm{Cg}_{3}-\mathrm{Cg}_{5}^{\prime}$ & $3.5991(9)$ & $1.02(7)$ & 20.0 & 21.0 & $3.3611(6)$ & 1.287 \\
\hline $\mathrm{Cg}_{3}-\mathrm{Cg}_{6}^{\prime}$ & $3.5769(9)$ & $0.68(7)$ & 20.6 & 20.7 & $3.3452(6)$ & 1.266 \\
\hline $\mathrm{Cg}_{3}-\mathrm{Cg}_{8}^{\prime}$ & $3.5307(9)$ & $10.80(7)$ & 26.1 & 15.3 & $3.4059(6)$ & 0.930 \\
\hline $\mathrm{Cg}_{5}-\mathrm{Cg}_{7}^{\prime}$ & $3.9723(9)$ & $12.43(7)$ & 33.4 & 25.6 & $3.5838(6)$ & 1.713 \\
\hline $\mathrm{Cg}_{6}-\mathrm{Cg}_{7}^{\prime}$ & $3.5732(9)$ & $13.42(7)$ & 22.5 & 14.8 & $3.4550(6)$ & 0.911 \\
\hline
\end{tabular}

(1): $\mathrm{Cg}_{1}$ is the center of the rings in $\mathrm{H}_{2}$ detba, $\mathrm{Cg}_{2}$ is the center of the ring in $\mathrm{Hdetba}^{-} . \mathrm{Cg}_{3}$ is the center of the ring $\mathrm{BipyrH}^{+} . \mathrm{Cg}^{\prime}{ }_{1}$ was obtained from $\mathrm{Cg}_{1}$ by the transform $(1-\mathrm{x}, 1-\mathrm{y},-\mathrm{z}), \mathrm{Cg}^{\prime}{ }_{2}$ was obtained from $\mathrm{Cg}_{2}$ by the transform $(1-\mathrm{x}, 1-\mathrm{y},-\mathrm{z}), \mathrm{Cg}_{3}^{\prime}$ was obtained from $\mathrm{Cg}_{3}$ by the transform $(2-\mathrm{x}, 1-\mathrm{y},-\mathrm{z}) . \mathrm{Cg}_{\mathrm{i}} \mathrm{p}$ is the distance between the center of the ring $\mathrm{Cg}_{\mathrm{i}}$ in the $\pi-\pi$ interaction.

(2): $\mathrm{Cg}_{1}, \mathrm{Cg}_{2}, \mathrm{Cg}_{3}$ and $\mathrm{Cg}_{4}, \mathrm{Cg}_{5}, \mathrm{Cg}_{6}$ are the centers of the rings in $\mathrm{PhenH}^{+}, \mathrm{Cg}_{7}$ and $\mathrm{Cg}_{8}$ are the centers of the rings Hdetba ${ }^{-} . \mathrm{Cg}_{4}^{\prime}, \mathrm{Cg}_{5}^{\prime}, \mathrm{Cg}_{6}{ }_{6}$ were obtained from $\mathrm{Cg}_{4}, \mathrm{Cg}_{5}, \mathrm{Cg}_{6}$ by the transform (-1+x,y,z), $\mathrm{Cg}_{7}^{\prime}$ was obtained from $\mathrm{Cg}_{7}$ by the transform (2-x,2-y,2-z), $\mathrm{Cg}_{8}^{\prime}$ was obtained from $\mathrm{Cg}_{8}$ by the transform $(-\mathrm{x}, 1-\mathrm{y}, 1-\mathrm{z})$. 


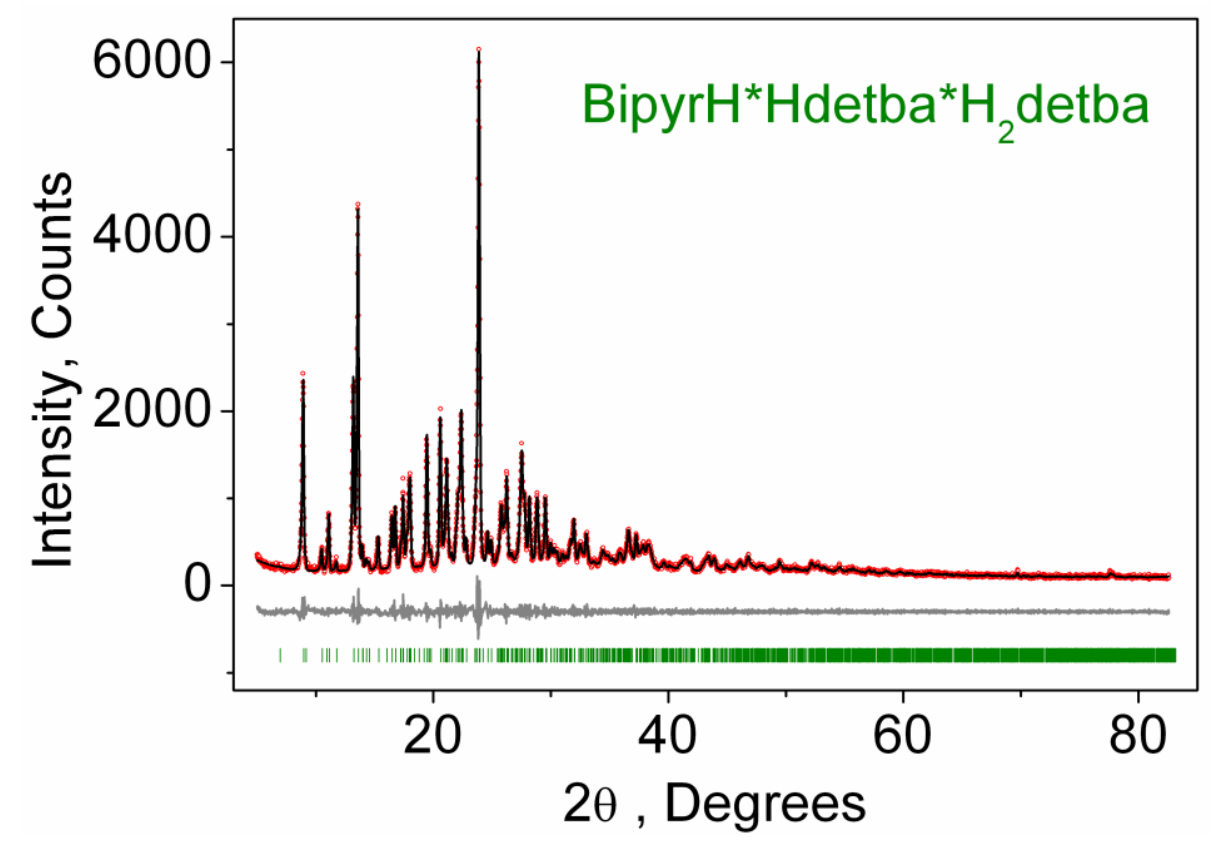

Fig. 1S Difference X-ray powder patterns of BipyH(Detba)(HDetba) (1) 


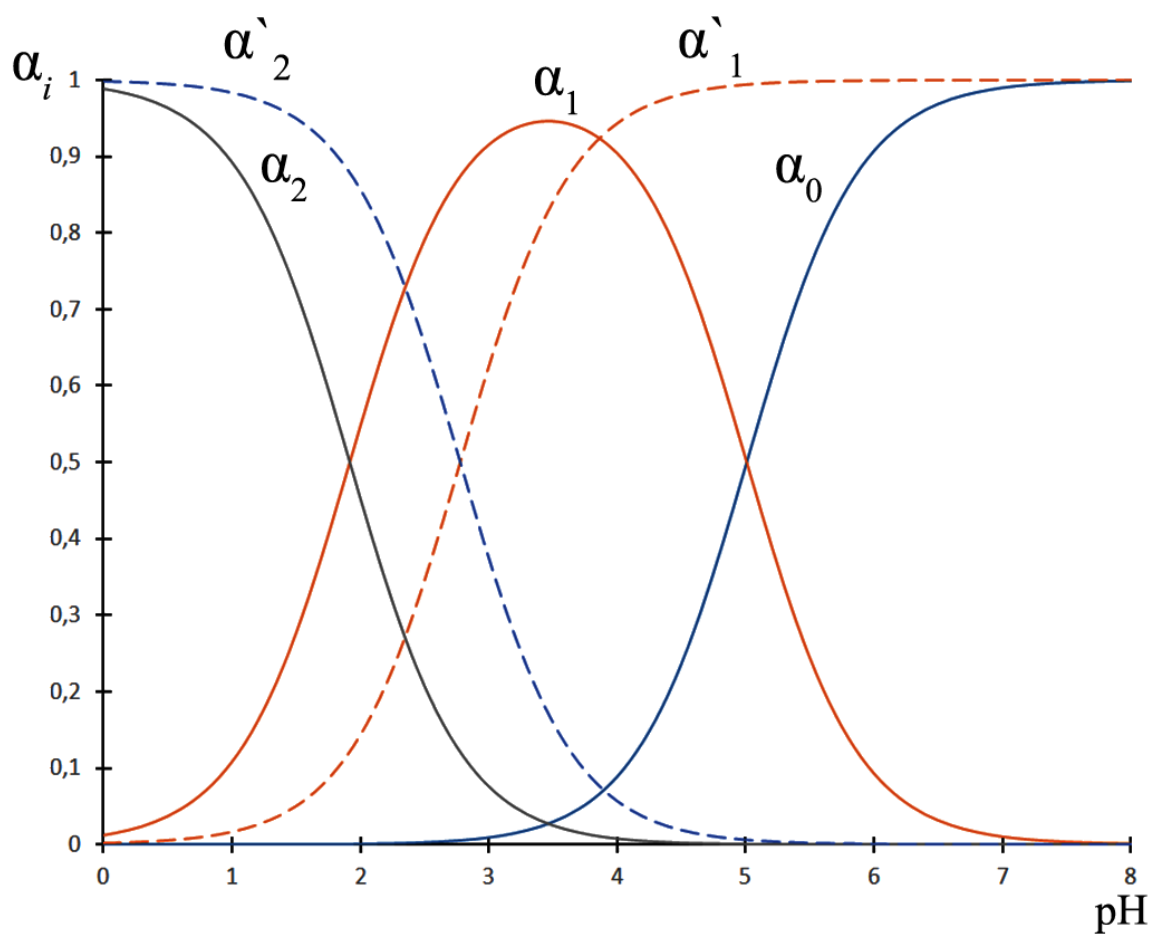

Figure 2S. Phen and HDetba distribution diagram of species molar part $\left(\alpha_{\mathrm{i}}\right): \alpha_{0}-$ Phen, $\alpha_{1}-$ $\mathrm{PhenH}^{+}, \alpha_{2}-\mathrm{PhenH}_{2}{ }^{2+} ; \alpha_{2}-\mathrm{HDetba}_{2} \alpha_{1}-\mathrm{Detba}^{-}$ 


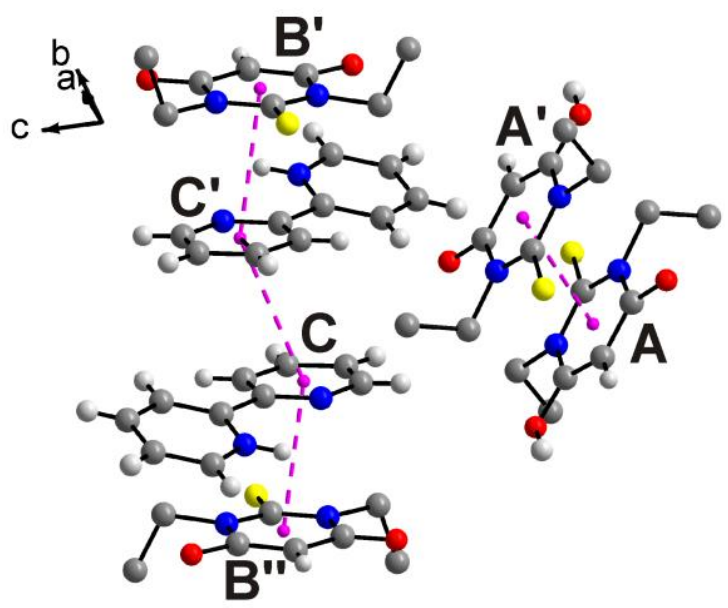

a)

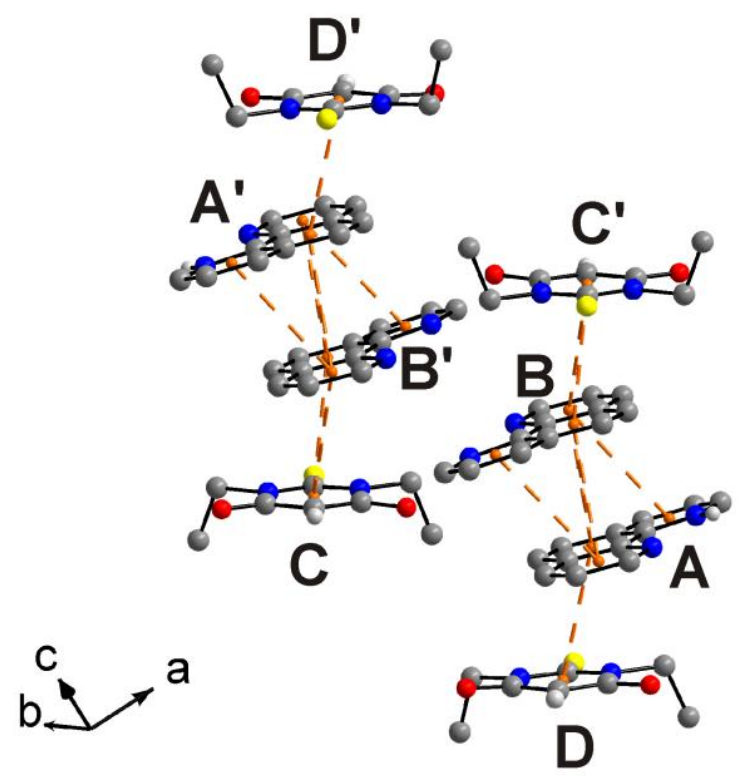

b)

Fig. 3S $\pi-\pi$ interactions between ring of the HDetba, Detba ${ }^{-}, \mathrm{BipyH}^{+}$ions/molecules in (1) (a), between the ring of the Detba ${ }^{-}$and $\mathrm{PhenH}^{+}$ions in (2) (b). 


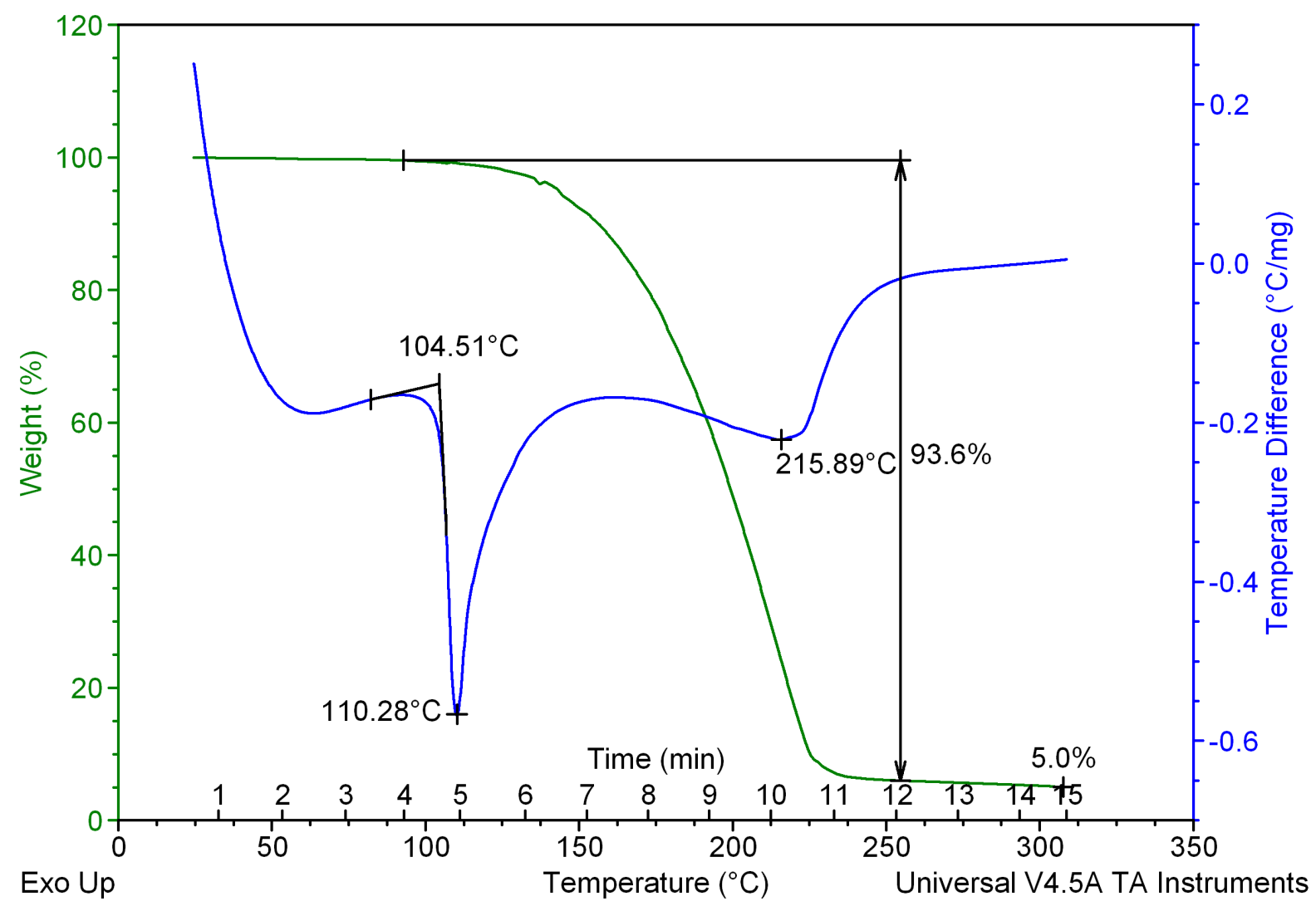

Fig. 4S. TG and DSC curves of (1) in air 


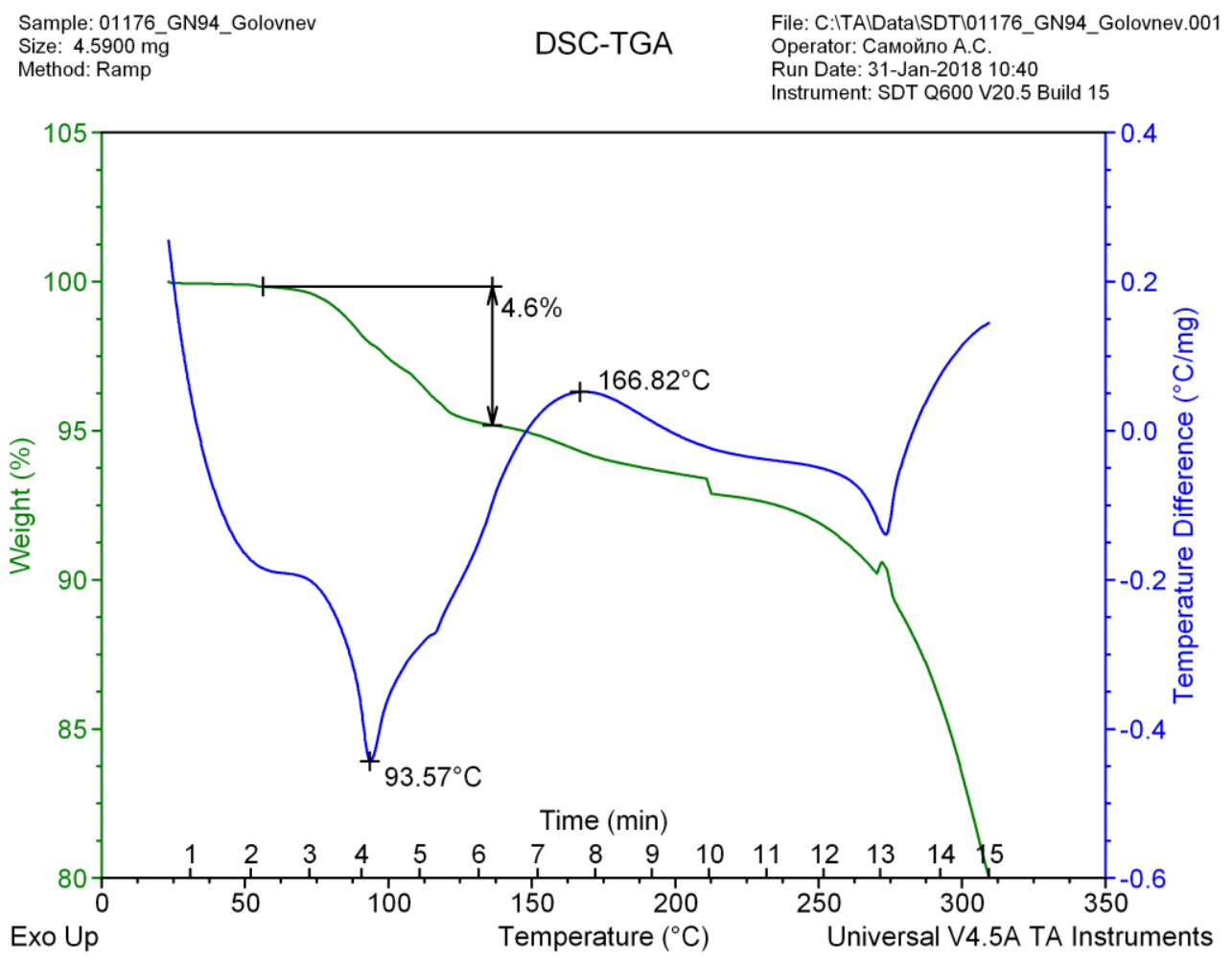

Fig. 5S. TG and DSC curves of (2) in air 